August 26, 2019

ESMT Working Paper 19-03

\title{
The impact of EU cartel policy reforms on the timing of settlements in private follow-on damages disputes: An empirical assessment of cases from 2001 to 2015
}

Hans W. Friederiszick, ESMT Berlin and E.CA Economics

Linda Gratz, E.CA Economics

Michael Rauber, E.CA Economics

Copyright 2019 by ESMT European School of Management and Technology GmbH, Berlin, Germany, https://esmt.berlin/. All rights reserved. This document may be distributed for free - electronically or in print - in the same formats as it is available on the website of the ESMT (www.esmt.org) for non-commercial purposes. It is not allowed to produce any derivates of it without the written permission of ESMT.

Find more ESMT working papers at ESMT faculty publications, $\underline{\text { SSRN, }} \underline{\text { RePEc}}$, and EconStor. 


\title{
The Impact of EU Cartel Policy Reforms on the Timing of Settlements in Private Follow-On Damages Disputes - An Empirical Assessment of Cases from 2001 to 2015
}

\author{
Hans W. Friederiszick, Linda Gratz and Michael Rauber*
}

Private cartel damages litigation is on the rise in Europe since early 2000. This development has been initiated by the European courts and was supported by various policy initiatives of the European Commission, which found its culmination in the implementation of the EU Directive on Antitrust Damages end of 2016. This paper explores the impact of this reform process on effective compensation of damaged parties of cartel infringements. For that purpose we analyse all European cartel cases with a decision date between 2001 and 2015, for which we analyse litigation activity and speed. Overall, we find a substantial reduction of the time until first settlement (increase in litigation speed) together with a persisting high share of cases being litigated (high litigation activity). This supports the view that the reform not only increased the claimant's expectation about the amount of damages being awarded, but also resulted in an alignment in the expectations of claimants and defendants in the final damages amount, i.e. the European Commission succeeded in reaching its objective to clarify and harmonize legal concepts across Europe.

Keywords: cartels, private damages, competition law

\footnotetext{
*Hans W. Friederiszick is a Director of E.CA Economics and Research Fellow of ESMT Berlin. He was Member of the Chief Economist Team of DG COMP from 2003 to 2006 and part of a DG COMP internal working group on economic methods for cartel detection. Linda Gratz is Principal and Michael Rauber Manager at E.CA Economics. Michael Rauber was until September 2014 an Assistant Director of Economics at the UK Competition and Markets Authority. Research support was received by Stefan Pauli and Brecht Boone. The authors would like to thank participants of the Antitrust Enforcement Symposium 2016 in Oxford for valuable comments. We would also like to thank a group of litigation practitioners who were available for interviews. All errors and omissions stay with the authors alone. Corresponding author: friederiszick@e-ca.com.
} 


\section{Introduction}

Private cartel damages litigation is on the rise in Europe since early 2000. Within the Courage and Crehan judgment in $2001^{1}$ and the Manfredi judgment in $2006^{2}$ the European courts clarified the right of all European citizens for compensation for competition law infringements. These and accompanying judgments as well as the political will to deter cartel behaviour effectively initiated various policy reforms by the European Commission. The policy reforms ought to enable harsh punishment of cartels and at the same time promote effective compensation of damaged parties of cartel infringements. This development found its current culmination in the implementation of the EU Directive on Antitrust Damages ("the Directive") end of 2016. The Directive marked an important step towards harmonization of national legal systems. ${ }^{3}$

Within that context, this paper explores the impact of this reform on effective compensation of damaged parties of cartel infringements. For that purpose we analyse all European cartel cases with a decision date between 2001 and 2015. Later cases are not introduced in order to prevent the analysis to be affected by a truncation problem. For these cases we calculate the share of cases being litigated (as a measure of litigation activity) and the timespan between the Commission Decision and private damages being claimed and settlements on private damages claims being reached (as a measure of litigation speed). Indeed, we find an increase in litigation activity over time and an increase in litigation speed.

Based on a theoretical model and in light of those empirical findings we conclude that the European Commission's policy reform was a success up to now:

First, in order to induce substantially higher private litigation activity a policy reform has to increase the claimant's expectations about the amount of damages being awarded, and/or must have induced lower litigation costs or shorten the expected duration until a final court judgement is delivered. Given that we observe a higher litigation activity the policy reform must have had a positive impact on those factors.

Second, the increase of litigation speed, measured by the timespan until the first settlement is reached, implies an alignment in the expectations of claimants and defendants in the final amount of damages being awarded. Given the persistently high litigation activity, we can exclude economically unattractive settlements, i.e. claimants being in despair, to be the cause for increase in litigation speed. This is consistent with the European Commission reaching its objective to clarify and harmonize legal concepts across Europe.

More in detail, we come to the following empirical findings:

Regarding cartel enforcement activity, the number of Commission Decisions related to cartel cases has been rather stable over the observation period, with 4 to 5 cartel decisions per year in most years with some years reaching up to 8 to 10 decisions per year. The level of cartel fines increased significantly from 2006 onwards with the new Fines Guidelines being implemented (slightly declining thereafter

\footnotetext{
${ }^{1}$ C-453/99 Courage and Crehan (20 September 2001).

2 Joined cases C-295/04 to C-298/04 Manfredi (13 July 2006).

3 The EU Directive on Antitrust Damages was adopted and signed into law end of 2014, requiring its implementation by Member States until end of 2016. As of 6 June 2018, all Member States implemented the directive into national law. See http://ec.europa.eu/competition/antitrust/actionsdamages/directive_en.html, accessed on 6 June 2019.
} 
though). Between 2011 and 2005 the average total fine per Commission Decision was around 125 Mio $€$, in later years until 2015 the average total fine varied between 280 and 365 Mio $€$ per case.

With respect to litigation activity, we find that the share of cases being litigated increased from 2001 to 2011 steadily, reaching its peak in 2011 at $70 \%$. In the last four years of our observation period (2012 to 2015), we observe some decline, coming from this relatively high level (average of $60 \%$ in the years 2009 to 2011) though. This decline of the share of cases litigated is in part driven by a slowdown of litigation activity, but also by an increasing number of cartel cases with smaller fines being litigated in recent years. Those "smaller" cases are less often litigated than "bigger" cases as measured by the level of fines, thereby pushing the overall share of cases being litigated down. Interestingly, smaller cases - while still less often being litigated than larger cases - are recently litigated more often than in earlier times.

Regarding litigation speed, we find for all cases, which attracted follow-on private litigation, a substantial reduction of the time until first settlement. While for the EC cartel cases decided between 2001 and 2005 it took on average 7.3 years from the EC decision date until a first settlement was announced, in 2006 to 2008 the duration fell to 6.4 years, in 2010 to 2011 to 4.2 years and in 2014 to 2.6 years. We tested here against a truncation bias, and can exclude that this drives the results.

Overall, we find a substantial reduction of the time until first settlement together with high litigation activity, consistent with the premise that the adopted reforms have increased legal certainty and thereby successfully implemented a legal framework of effective compensation of damaged parties.

Clearly, also other factors may have caused this development towards higher litigation activity and speed. For example, the experience gained over time by both defendants and claimants and their external consultants may have reduced litigation costs and allow speedier negotiation processes. However, this development seems to be deeply intertwined with the political reform process and, hence, cannot be considered an independent (albeit important) factor.

Further, higher litigation costs caused through the promotion of litigation in multiple jurisdictions can make settlements more likely and hence may lead to earlier settlements. It seems unlikely, though, that higher litigation costs due to litigation in multiple jurisdictions has been the key driver of the development as most of the visible litigation action during the observation period was centred on a few countries, namely UK, Germany and the Netherlands. More in general the lasting high level of litigation activity speaks against higher litigation costs. To the opposite: the higher share of smaller cartel cases being litigated indicates a reduction in litigation costs, allowing economically valuable litigation also for cases with lower expected damages payments.

The main body of this article is structured along the following lines. In Section II, we analyse past changes in the regulative and business environment and discuss likely impacts on legal uncertainty and litigation costs. In Section III, we describe a theoretical framework of settlements, specifically the factors driving the incentives of claimants and defendants to settle early. In Section IV, we present our empirical results on the development of the timespan between public and private enforcement. Section $\mathrm{V}$ discusses the policy conclusion. 


\section{Related Literature}

Our paper is closely related, and builds upon the literature on the decision to settle a case instead of to litigate. Rubinfeld (2015) offers an introduction into that literature in relation to antitrust cases. A broader review of the literature on litigation activity is offered by Spier (2007). Rubinfeld (2015) points to four factors identified in the literature for affecting settlement decisions: (1) savings in litigation costs compared to settlement costs, (2) risk aversion of the parties (the more risk averse, the more they want to avoid the uncertain outcome of litigation), (3) divergence of the parties' expectations regarding their own success in court, and (4) reputational effects (defendants might put a higher value on their potential losses in court than claimants). In our theoretical section we adopts their framework to our institutional setting.

On the empirical literature, Perloff et al. (1996) estimate the determinants to settle based on a dataset covering all private antitrust suits filed from 1973 to 1983 in five US federal district courts, of which $24.4 \%$ concern price fixing. ${ }^{4}$ They find that court, industry and firm size matter in determining the success at trial and the probability for a settlement. The estimated probability of claimants winning in court would be lower in cartel cases than in merger, price discrimination, tying and dealer termination cases and higher than in predation, refusal to deal and vertical restraints cases. The estimated probability of a settlement would be highest in cartel cases. Quantitatively, for every 1 percent increase in the probability that the claimant wins, ${ }^{5}$ the probability that the case settles rises by nearly 0.13 percent. ${ }^{6}$ This effect would increase with the size of damages awarded. It suggests that policy reforms that positively affect the claimants' probability of winning in court increases settlement rates.

On the more specific question of the timing of settlements, only a few empirical papers offer an assessment. Boyd and Hoffmann (2012) look at federal district court data and find that motions can speed up settlements due to parties gaining knowledge about their own case. Johnston and Waldfogel (2002) look at repeated interactions between lawyers and find that swifter compromise is reached if lawyers interact more frequently. Fenn and Rickman (1999) find that parties' cost and liability calculations as well as legal aid has an important impact on settlement timings in cases against the NHS trusts in England. ${ }^{7}$

Another strand of the literature related to our work analyses the development of cartel enforcement over time and explores the revealed motives behind observable changes. Ghosal and Sokol (2016), for instance, analyse the US cartel enforcement activity during the period 1969 to 2013 (and to some limited extent also European cartel cases). They identify different policy regimes during that period and explore the impact of those policy changes on cartel prosecution outcomes. The impact of the different policy regimes on private litigation is not analysed, though.

\footnotetext{
${ }^{4}$ There is also a literature about settlements within the administrative proceedings (Hellwig et al. 2018). This is, however, a different type of settlement as this literature is i) focussing on the period before a decision is taken by the competition authority, ii) one of the parties in the negotiations is the competition authority and iii) the outcome is a (reduced) fines payment.

5 The estimated probability that the claimant wins is based on the size of the parties, the jurisdiction, the parties' industries, and whether a jury or class action is requested. For example, the authors estimate that smaller claimants/ defendants are less successful in court than mid-size claimants/ defendants.

${ }^{6}$ Similarly, the authors estimate that if the claimant demands a jury, this increases the claimant's probability of winning in court by $40 \%$ and the settlement probability by 81 percentage points.

7 Their theoretical framework is provided by Spier (1992), who explores a dynamic model of settlements where the defendant has private knowledge about the outcome of the trial.
} 
There is also a wide literature on leniency. Riley (2010) offers a detailed overview of the EU Commission's leniency program and its success as measured by the number of leniency applications. Aguzzoni et al. (2013) show that the number of cases and leniency applicants have risen dramatically since 2003, relative to earlier periods. A review of the economic evidence is given by Spagnolo and Marvao (2016). They point out that leniency reductions have been granted to $52 \%$ of all EC cartel fines (1998 to 2014) with on average four leniency recipients per cartel case.

Beyond, Bourjade, Rey and Seabright (2009) discuss the selection problem of courts to distinguish liable from non-liable defendants. They conclude that policy reforms should rather be directed towards increasing damages than reducing litigation costs to ensure that those who have broken the law face significantly higher costs than those who have not.

Finally, there are several papers which empirically assess the litigation activity related to competition harm in Europe over the relevant time period, namely Waelbroeck et al. (2004), Schinkel (2007), Renda et al. (2007), Russo et al. (2010), Laborde (2017), and Sailer (2019) on cases in the EU, Rodger (2008, 2015) on cases in the UK, and Peyer (2012) and Rengier (2018) on cases in Germany. Some of these latter papers will be summarized more carefully in the following section, reviewing the reform process. 


\section{EU Policy Reform and its Likely Impact on the Timing of Settlements in Follow-On Damages Disputes}

Private cartel damages litigation is on the rise in Europe since early 2000. Within the Courage and Crehan judgment in $2001^{8}$ and the Manfredi judgment in $2006^{\circ}$, the European courts clarified the right of all European citizens for compensation in case of competition law infringements. These and accompanying judgments as well as the political will to deter cartel behaviour effectively initiated various policy reforms by the European Commission to enable harsh punishment of cartels and at the same time to promote effective compensation of victims of cartel infringements. This development found its current culmination in the implementation of the EU Directive on Antitrust Damages ("the Directive"), which was implemented end of 2016 and marked an important step towards harmonization of national legal systems. ${ }^{10}$

\section{A. The evolution of the EU reform on private damages}

In the following, we describe the main policy changes and discuss their likely impact on litigation activity and the timing of settlements. The existing evidence on litigation activity is summarized. ${ }^{11} \mathrm{We}$ distinguish three main periods:

i) the early phase of the reform process (before 2000 until the publication of the Greenbook end of 2005), during which the political will to strengthen private enforcement was expressed and policy options were explored to overcome obstacles to sue;

ii) the mid-phase of the reform process (from 2006 until the publication of the Directive in mid-2013), during which the European way to private enforcement was agreed upon;

iii) and the late phase of the reform process (from mid-2013 until today), during which the Directive was implemented into national laws.

The reform process is an open-ended process as important design questions, e.g. on collective redress, are still being addressed.

Early phase of the reform process - identifying obstacles to sue (before 2000 until 2005)

Private enforcement of antitrust rules, in principle, has been feasible in the EU since the Treaty of Rome came into force in 1958. Actual litigation activity, in particular, if one focuses on follow-on cases in relation to EU cartel infringements (which are in the focus of this paper) was rather limited in the early years.

One reason for this was the rather dysfunctional anti-cartel enforcement regime of the European Commission during that time. Between 1958 and 1998 the Commission only adopted on average one

${ }^{8}$ C-453/99 Courage and Crehan (20 September 2001).

9 Joined cases C-295/04 to C-298/04 Manfredi (13 July 2006).

10 The EU Directive on Antitrust Damages was adopted and signed into law end of 2014, requiring its implementation by Member States until end of 2016. As of 6 June 2018, all Member States implemented the directive into national law. See http://ec.europa.eu/competition/antitrust/actionsdamages/directive_en.html, accessed on 6 June 2019.

11 Several empirical sources for litigation activity exist in the literature, namely Waelbroeck et al. (2004), Schinkel (2007), Renda et al. (2007), and Russo et al. (2010) on cases in the EU, Rodger (2008, 2015) on cases in the UK, and Peyer (2012) on cases in Germany. 
cartel decision per year. ${ }^{12}$ It was only with the intensified enforcement in the US and the Commission's implementation of a leniency program (1996, 2002, and 2006) that enforcement activity increased substantially, pathing the way for follow-on damages claims.

A further push came from the European Courts. It was only with the judgments of the European Courts, i.e. the Courage and Crehan judgment in $2001^{13}$ and then later the Manfredi judgment in $2006^{14}$, that private enforcement of competition law infringements became a priority for European policy makers.

The introduction of regulation 1 / 2003, which came into effect in 2004, marked another major change in the legal landscape in Europe with respect to cartels. It shifted the enforcement of Article 101 TFEU from the Commission's centralized assessment towards a decentralized enforcement of EU competition rules, enabling national courts to rule on antitrust claims brought by affected individuals.

With the Greenbook of the European Commission, published end of 2005, the stake taking exercise in identifying obstacles for effective compensation hit its first milestone. Still during this phase, litigation was hampered by legal uncertainty. The respondents to a questionnaire send out by Rodger (2015), for instance, indicated legal uncertainty being a major factor for not initiating private litigation. ${ }^{15}$ Equally, a study by Peyer (2012), covering litigation activity during the years 2005 to 2007 in Germany, shows increasing numbers of appeal cases, indicating a remaining high level of legal uncertainty in the early phase. ${ }^{16}$

Accordingly, litigation activity was rather limited during that time. A study by Ashurst (Waelbroeck et al., 2010) commissioned by the EU Commission lists cases litigated in Europe. The authors find that in most EU Member States not a single case was brought. Only in France, Germany, Italy, and to a limited extent in the UK, the authors identified active litigation. ${ }^{17}$ In fact, the Vitamins case brought in Germany (2004; district court Dortmund, p. 49) is the only true EU cartel case identified - other cases identified in the study actually concern excessive pricing or bid rigging in public tenders for the development of waterways. Another case in the UK, the Crehan case, found its way to the European Courts but was not a standard cartel case either, as damages were awarded in relation to the effect of anticompetitive constraints in a lease contract. ${ }^{18}$

While the European courts delivered with the Courage and Crehan judgment in $2001^{19}$ and the Manfredi judgment in $2006^{20}$ important case law and clarified the right of all European citizens for compensation for competition law infringements also in the later years 2005/ 2006 of this period, litigation activity - to the extent it was visible at that time - did not accelerate significantly. Renda et al. (2007) identify only in 10 of 27 Member States "traces of private antitrust damages actions". Over

\footnotetext{
12 Harding, C. and Joshua, J. (2003), "Regulating Cartels in Europe: A Study of Legal Control and Corporate Delinquency", Oxford: Oxford University Press, Chapter V and Table V.1: “Cartels dealt with by the Commission 1964-1987”. Cited according to Riley (2010).

${ }^{13}$ C-453/99 Courage and Crehan (20 September 2001).

14 Joined cases C-295/04 to C-298/04 Manfredi (13 July 2006).

${ }^{15}$ Rodger (2015), Table 12.

16 Peyer (2012, Table 1, p. 339) shows that the number of litigation case being appealed increases from $40 \%$ in 2005 to 50

$\%$ in 2007 (first instance appeal) and from 6\% in 2005 to 8\% in 2007 (highest appeal instance).

${ }_{17}$ Waelbroeck et al (2004), p. 43.

${ }_{18} \mathrm{Mr}$ Crehan, a pub owner, sued Inntrepreneur Pub Company $\mathrm{CpC}$ regarding beer tie restrictions in his lease contracts for two pubs, forcing him to supply beer at a price above the competitive wholesale level.

${ }^{19}$ C-453/99 Courage and Crehan (20 September 2001).

${ }^{20}$ Joined cases C-295/04 to C-298/04 Manfredi (13 July 2006).
} 
the period from May 2004 to the third quarter of 2007, only 13 EU cartel litigation cases were identified, however, only two of them related to EU cartel cases, namely the Vitamins case and the Italian Rc Auto cartel case. ${ }^{21}$

Equally, studies at national level, such as by Rodger (2008) ${ }^{22}$ for the UK and by Peyer (2012) for Germany, identify significantly more litigation activity in general (on vertical cases; national cases; standalone; abuse of dominance cases; injunctions; patent related cases, etc.) but no or rather limited additional litigation activity regarding EU follow-on cartel cases. Rodger (2009), for instance, identifies for this period litigation related to the EU Vitamins decision (Devenish and BCL Old Co) and to Electrical Mechanical Carbon and Graphite Products only.

Mid-phase of the reform - agreeing on a European way to private enforcement (2006 to mid2013)

In Europe, the administrative enforcement and associated fines have been the main driving force of cartel deterrence. ${ }^{23}$ With a further reform of the leniency program in 2006, establishing a marker system and a tighter enforcement of cartel activity in general, detection pressure on cartels significantly increased in Europe. The Commission also introduced new Fine Guidelines in 2006, which replaced the Fine Guidelines from 1998. These Fine Guidelines constituted an important milestone not only for the administrative enforcement but also for private litigation of follow-on claims.

The following Figure 1 shows the average total fines per Commission Decision for the time between 2000 and 2017. As can be seen, under the new Fine Guidelines in 2006 the average total fine increased substantially on average. Even though the average amount of affected sales and number of undertakings per cartel was relatively low in 2015 to 2017, the average total fine remained high, in particular in 2016, in which the trucks cartel decision was taken. ${ }^{24}$

\footnotetext{
${ }^{21}$ Renda et al. (2007), p. 39 to 42.

22 While a country specific study allows for a more comprehensive case search it is equally affected by a "visibility bias". As pointed out by Rodger (2013, p. 110) in the UK, for instance, only cases which are brought at the CAT leave a 'footprint' - even if settled - while litigation at commercial courts are in this case not visible. The same is true for Germany (see Peyer, 2012, p. 336-337). While the courts are obliged to inform the FCO about cases in which a dispute arises out of the application of either European or German antitrust law, lawsuits which are terminated, e.g. by settlement, or claims which are withdrawn are not reported.

23 This is different in the US, where in the early years of private litigation in the 1950s, 75 percent of the litigation activity was related to follow-on damages cases. More recent evidence shows an increasing fraction of cases being stand-alone cases; around 50 percent of the cases are uncovered by private attorneys as opposed to government agencies. See summary in Rodger (2013), p. 107 and Lande and Davis (2008).

${ }^{24}$ The fine per undertaking also increased since 2006, again with a peak value in 2016 due to the trucks cartel.
} 
Figure 1: $\quad$ Average total fine per Commission Decision, 2001 to 2015

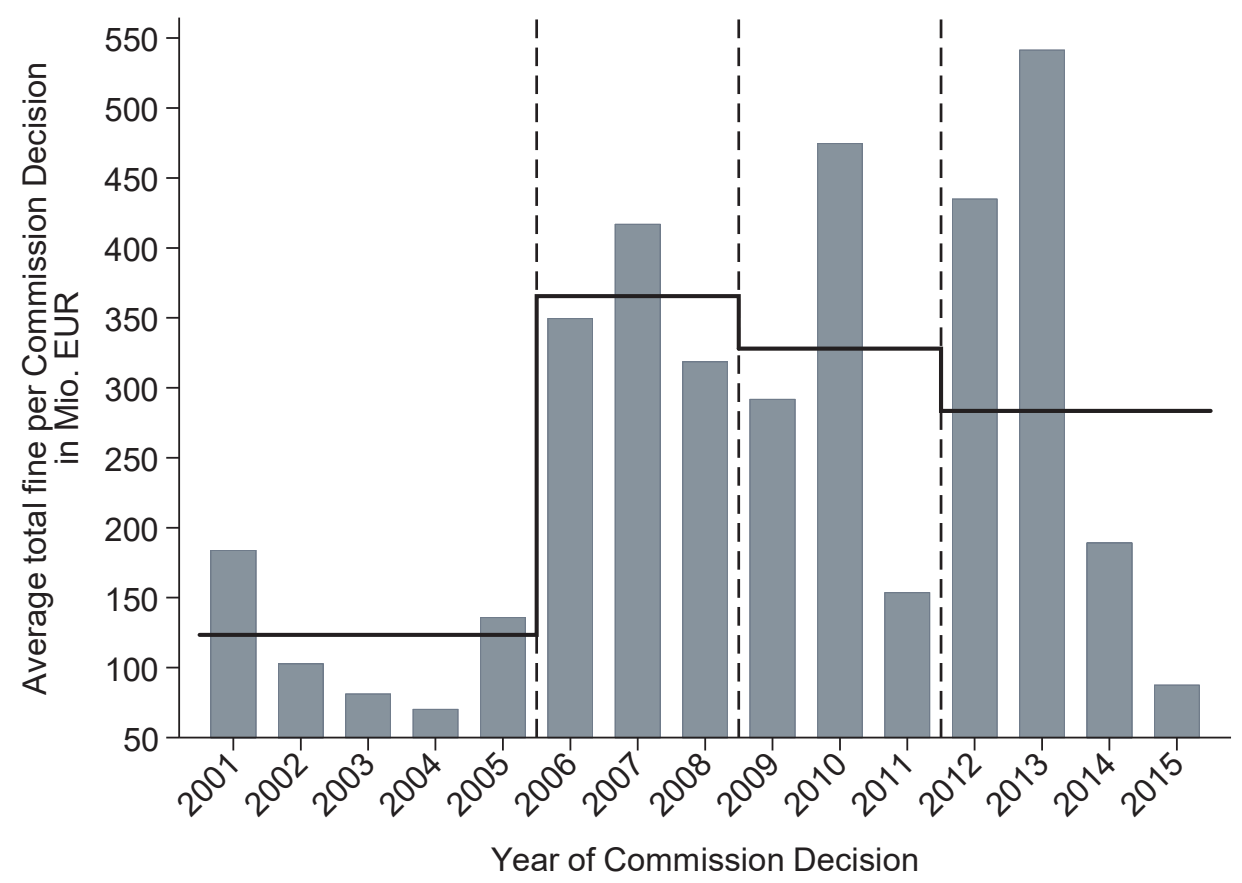

Note: This graph is based on 90 decisions of the European Commission for 2001 to 2015. The horizontal black lines represent the simple average of total fines for 2001-2005, 2006-2008, 2009-2011 and 2012-2015 respectively.

Source: The authors.

In our view, the level of fines became an important driving factor also for private litigation. It is perceived that the new Fine Guidelines better link the fines to the overall economic significance of the infringement and the share of each company involved. ${ }^{25}$ The Fine Guidelines therefore provide better information about the significance of the infringement and the potential value of a claim.

In particular, it is regulated under the Fine Guidelines that fines are based on a percentage of yearly sales up to a maximum of 30 percent multiplied by the number of years of participation in the infringement. A fixed entry fee equal to 15 to 25 percent of annual EEA sales is added as a further deterrent. Other aggravating or mitigating factors are taken into account.

In comparison, the previous Fine Guidelines from 1998 were less clear around the potential scope of the infringement as fines were not explicitly linked to sales during the infringement. ${ }^{26}$ There was no entry fee and aggravating and mitigating factors differed, in particular in case of repeat offenders. ${ }^{27}$

As an important implication of the clarity brought by the new Fine Guidelines the duration of appellate court proceedings reduced. According to Smuda et al. (2014) the average duration of a first stage court investigation decreased by around 12 months and of a second stage appeal by 11 months. These mark

\footnotetext{
${ }^{25}$ See http://europa.eu/rapid/press-release_IP-06-857_en.htm?locale=en, accessed on 17. June 2016.

${ }^{26}$ For minor infringements, fines were likely between EUR 1,000 and EUR 1 million, for serious infringements between EUR 1 and 20 million and for very serious infringements above EUR 20 million. Guidelines on the method of setting fines imposed pursuant to Article 15 (2) of Regulation No 17 and Article 65 (5) of the ECSC Treaty, \$1. A.

${ }^{27}$ See http:/ / europa.eu/rapid/press-release_IP-06-857_en.htm?locale=en, accessed on 17. June 2016.
} 
substantial reductions given the average duration of 49-months for a first stage appeal and a 16-month duration for a second stage appeal. ${ }^{28}$

The increased fine level also showed the commitment of the Commission to further tension its grip on illegal cartel activity. Having laid out the options in the Green book, the White book, which was published in 2008, condensed the discussion and focused on a few options. In the European wide discussion process with stakeholders a balanced position was derived and implemented in the EU Directive on Antitrust Damages. ${ }^{29}$ The EU Directive on Antitrust Damages was adopted and signed into law in November 2014. Members States had to implement the Directive in their legal systems by 27 December 2016. At about the same time, several important decisions of the European court further clarifying the legal framework. ${ }^{30}$ However, the Commission also introduced its Settlement Notice in 2008. ${ }^{31}$ The Settlement Notice provides incentives to companies involved in a cartel to settle with the Commission, speeding up the procedure for adoption of a cartel decision. Consequently, the number of settlements with the Commission increased in parallel and less information was disclosed to parties in follow-on claims.

The Directive on Antitrust Damages, implemented in 2014, introduces a number of changes to achieve its main aims, which are effective compensation of damaged firms due to antitrust infringements and optimization of the interaction between public and private enforcement. ${ }^{32}$ Furthermore, the Directive aims to further harmonize national law, thereby incentivizing a broader, pan-European coverage of legal action.

The main changes introduced with the Directive are the following: $:^{33}$

- Clear limitation period rules are established, so that claimants have sufficient time to bring an action. In particular, victims will have at least five years to bring damages claims, starting from the moment when they had the possibility to discover that they suffered harm from an infringement. This period will be suspended or interrupted if a competition authority starts infringement proceedings, so that victims can decide to wait until the public proceedings are

\footnotetext{
${ }^{28}$ The empirical assessment is based on a dataset of all EC cartel decisions decided between 2000 and 2012. The impact of the 2006 Fines Guidelines of the duration of court decision is based on an econometric model, introducing a dummy variable after its introduction. See Smuda et al. (2014).

${ }^{29}$ Directive 2014/104/EU of the European Parliament and of the Council of 26 November 2014 on certain rules governing actions for damages under national law for infringements of the competition law provisions of the Member States and of the European Union, available online at http://ec.europa.eu/competition/antitrust/actionsdamages/directive_en.html. The directive entered into force on 25 December 2014, twenty days after its publication in the EU's Official Journal.

${ }^{30}$ Important judgements during this period have been: KZR 75/10 - ORWI (June 2011) on pass-on defence and standing of indirect purchasers in German proceedings; C-360/09 - Pfleiderer (14 June 2011) on documents and information provided under a national leniency programme and possible negative effects of third-party access to such documents on the effectiveness and proper functioning of cooperation between the authorities forming the European Competition Network; C-199/11 - Europese Gemeenschap vs Otis NV and Others (6 November 2012) on the possibility of the Commission to bring an action, on behalf of the EU, before a national court; C-536/11 Donau Chemie (6 June 2013) on third-party undertakings wishing to bring an action for damages and their right of access to the investigation file; C-557/12 Kone (5 June 2014) on loss resulting from the higher price charged by an undertaking as a result of a prohibited cartel to which it is not a party ('Umbrella pricing').

${ }^{31}$ Commission Notice 2008/C 167/01 on the conduct of settlement procedures in view of the adoption of Decisions pursuant to Article 7 and Article 23 of Council Regulation (EC) No 1/2003 in cartel cases, available online at https:/ / eurlex.europa.eu/legal-content/EN/ALL/?uri=CELEX:52008XC0702(01).

32 Friederiszick, H. W. (2013), "The Damages Lie in the Details: Why the Proposed Directive Fails in Harmonizing Incentives to Sue Across the European Union“, CPI Antitrust Chronicle, August 2013 (1).

33 Source: http://ec.europa.eu/competition/antitrust/actionsdamages/directive_en.html, accessed on 16. June 2016.
} 
over. Once a competition authority's infringement decision becomes final, victims will have at least one year to bring damages actions.

- The Directive clarifies the legal consequences of claimants "passing on" damages to their customers. It stipulates that compensation for passed-on amounts of price overcharges caused by a cartel is in fact owed to indirect customers. However, since it is difficult for indirect customers to prove that they suffered this pass-on, the Directive facilitates their claims by establishing a rebuttable presumption that cartels cause harm, the exact amount to be estimated by the judge. The Directive also contains provisions to avoid that claims by both direct and indirect purchasers lead to overcompensation.

- Any participant in an infringement will be responsible towards the victims for the whole harm caused by the infringement (joint and several liability), with the possibility of obtaining a contribution from other infringers for their share of responsibility. However, to safeguard the effectiveness of leniency programmes, this will not apply to infringers which obtained immunity from fines in return for their voluntary cooperation with a competition authority during an investigation; these immunity recipients will normally be obliged to compensate only their (direct and indirect) customers. Furthermore, a narrow exception from joint and several liability is foreseen under restrictive conditions for SMEs that would go bankrupt as a consequence of the normal rules on joint and several liability.

- The Directive determines that parties shall have easier access to evidence they need in actions for damages. Judges shall ensure that disclosure orders are proportionate and that confidential information is duly protected.

The following effects of these reform steps on settlement timing can be expected. The new rules on limitation periods and passing-on are likely to reduce legal uncertainty around private damages actions and make the course of legal proceedings better foreseeable for the parties. This should reduce the time until first settlements. Furthermore, the new rules on joint and several liabilities should make litigation for the claimants less complex and for the defendants more complex. Claimants should therefore be less inclined to settle and defendants more. The overall effect on settlement timing is unclear. Finally, the new disclosure rules should speed up proceedings, lowering litigation costs for both parties, having a negative effect on settlement timing.

Besides the clarification of legal concepts, the Commission engaged in an active advocacy process in order to support national judges in the application of private enforcement cases. The Guidelines on the quantification of damages (2010) mark an important milestone here, with the underlying Oxera study and the therein depicted meta-analysis of percentage overcharges offering a simple starting point for claimants to calculate the value of their claim.

\section{Late phase of the reform - implementation of the Directive in national law (mid-2013 to today)}

With the Directive being adopted, an important step towards harmonization of national legal systems was achieved. The EU Directive on Antitrust Damages was signed into law end of 2014, requiring its implementation by Member States until end of 2016. As of 6 June 2018, all Member States implemented the directive into national law. ${ }^{34}$

\footnotetext{
34 See http://ec.europa.eu/competition/antitrust/actionsdamages/directive_en.html, accessed on 6 June 2019.
} 
As a consequence, one observes an increasing number of multi-jurisdictional claims. Figure 2 shows the number of jurisdictions in which private damages litigation occurred. ${ }^{35}$

Figure 2: $\quad$ Share of multi-jurisdictional cases, 2001 to 2005 and 2006 to 2015
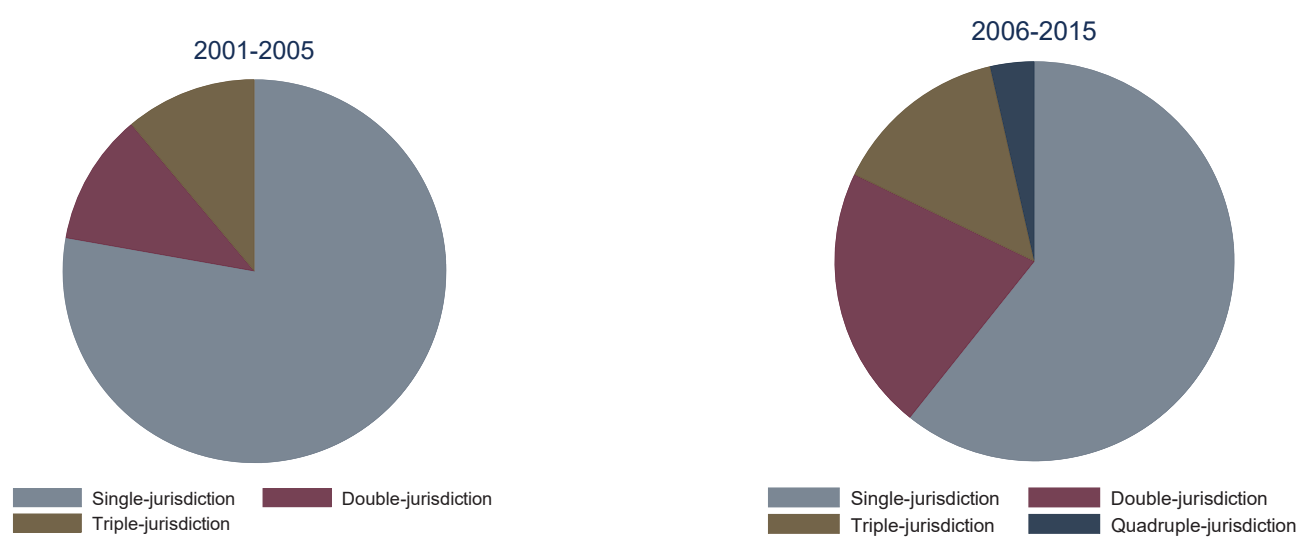

Note: The analysis is based on private claims following nine Commission Decisions for the years 2001 to 2005 and 28 Commission Decisions for the years 2006 to 2015. Private claims, for which no jurisdiction is known, are not included. Source: The authors.

As can be seen, for most cases, a single jurisdiction applies. More recently, however, the number of cases with litigation in more than two Member States increased. As can be seen in the appendix this trend is however not stable and various strongly over different time periods.

In parallel, and partially driven by the expectation of increasing transaction costs of multi-party, multijurisdictional litigation the Commission also supported collective redress mechanisms. Collective redress allows claimants facing the same defendant to enforce their rights collectively where they would not have done on an individual basis because of the cost or the time that it entails.

In its recommendation published in June 2013, the Commission pushes for an implementation of collective mechanisms at national level for both injunctive and compensatory relief concerning violations of rights granted under Union Law (such as competition law) and sets out the common principles that should be followed by national collective redress mechanisms. ${ }^{36}$ Member States were requested to put the recommendation in place by 26 July $2015 .{ }^{37}$

This reform step should in principle lead to more follow-on litigation. Based on the choices made by national Member States in implementing those recommendations, class action is by now seen in the UK, in many other Member States third party vehicles are more common legal practices for collective action. ${ }^{38}$

\footnotetext{
35 The dataset is described in Section V.A.

${ }^{36}$ Commission recommendation "on common principles for injunctive and compensatory collective redress mechanisms in the Member States concerning violations of rights granted under Union Law", C(2013)3539.

${ }^{37}$ European Commission „A framework for collective redress (class actions)“, accessed on 5th of December 2017 at: http://eur-lex.europa.eu/legal-content/EN/TXT/?uri=LEGISSUM:090402_1.

38 Class actions were introduced in UK with the Consumer Rights Act 2015, making it easier for groups of consumers to seek compensation for cartel infringements. The Act introduced "opt out" actions where everyone affected is automatically a member of the "class" which is suing.
} 


\section{B. Assessment of the EU policy reform - "actions for damages"}

In the following, we discuss the likely impact of the above described policy reforms on a constructive policy reform. With a constructive policy reform we mean, coming from a dysfunctional system in the past, that induces more litigation activity. ${ }^{39}$

1. Increase of the damages payment expected by the claimant in case of court ruling;

2. Alignment of parties' expectations regarding court ruling;

3. Reduction of litigation costs;

4. Reduction of litigation duration.

What becomes clear from the description of the above reform process by the European and national courts and Member States is that it does not exhibit a single "break-point" but should rather be described as a steady, long-term reform process with an impact over the entire period from 2001 until today. Still, despite its fluid status, the factors the policy reform attempts to change are rather transparent.

The following table summarizes our assessment.

Table 1: $\quad$ Assessment whether the EU policy reform process takes up elements of a constructive policy reform

Elements of a constructive policy reform

\begin{tabular}{lc}
\hline Increase of the expected payment in case of court ruling & Increase \\
\hline Alignment of parties‘ expectations regarding court ruling & Alignment \\
Reduction of litigation costs & Reduction/ ambiguous \\
Reduction of litigation duration & Reduction/ ambiguous \\
\hline
\end{tabular}

Source: The authors.

Regarding the reform's impact on the payment a claimant can expect in case of a final court ruling, it is at the heart of the reform process to raise these expectations. The fundamental support by European Courts to the principle of compensation, the Commission's own intensified action against illegal cartel activity, as documented in the changes of the Fine Guidelines, and its steps taken with the Directive itself clearly signal potential claimants increasing opportunities to receive substantial payments in return for bringing a claim. The, often heavily criticized, average overcharge of around $20 \%$ as reported by Connor/ Oxera may also have steered expectations by claimants upwards.

With respect to the criterion of an alignment of parties' expectations regarding court ruling the reform process - at least in its later phases - should have brought such an alignment. Clarification on the quantification topic, as the non-allowance of double or triple damages like in the US, the acceptance of interest from the point of time of damages, acceptance of umbrella effects, pass on and on the standard methods

\footnotetext{
${ }^{39}$ Note, that we do not make here any welfare judgements of whether more or less litigation activity is good or bad. These would require a welfare judgement which we cannot offer in the given setting.
} 
applied, did bring expectations to some alignment. Also important rulings on disclosure, jurisdictional questions, and standing of indirect customers reduced legal uncertainty substantially over time.

The implication of the reform process with respect to the third and the forth element of a constructive policy reform is less clear: while the reduction of legal uncertainty in itself (1) reduces litigation costs and (2) limits room for (strategic) delay in the proceedings, some elements of the European system are rather complex and may not allow for a litigation system that is as streamlined as in the US. Allowing standing of indirect purchasers and pass on results in duplication of quantification effort and court proceedings across different courts with conflicting interests of the various parties. The ambition of active litigation across Europe promotes multi-jurisdictional claims, adding complexity to the cases, and hence increases costs and leads to further delay. The half-hearted introduction of collective relief and its limited acceptance in practice results in high transaction costs in cartel cases with many affected parties. Overall, the impact of the EU policy reform process on the duration and costs of litigation seems ambiguous to us. 


\section{A Conceptual Framework}

To evaluate the impact of the EU reform process on effective compensation of victims in cartel infringements, a natural starting point would be to use the number of cases litigated and the monetary outcome of this litigation activity, discounted to the point in time when the damages occurred. ${ }^{40}$ However, while public data on the number of cases litigated is available, public data on the monetary outcome is usually not: until now, no or very few court decisions are available. ${ }^{41}$ Settlement amounts typically do not get public either as most settlement agreements are considered highly confidential.

For the study at hand, we can instead use public data on whether and when a settlement has been agreed. This information is regularly available as firms, in particular those quoted at stock exchanges, have to inform their shareholders on ongoing litigation and, hence, have to inform them when litigation risks are (partially) resolved, i.e. a settlement is reached. ${ }^{42}$

The impact of a policy reform on the timing of settlements is not straightforward, though: an early settlement at a low settlement amount speaks against, an early settlement at a high settlement amount speaks in favour of a successful empowerment of claimants. Furthermore, a policy reform potentially affects the bargaining position of claimants and defendants at several dimensions in parallel, with nonobvious consequences on the timing of settlements.

To better understand the impact of a policy reform on the timing of settlements we introduce in this section a Nash bargaining framework of settlement negotiations. We use a simplified version of the framework Rubinfeld (2015) describes, which is based on Perloff et al. (1996), Chapter II. The framework allows analysing the relationship between settlement timing, the importance of parties' expectations about the litigation outcome, the institutional environment as well as litigation costs. We explore the impact of a policy change on the various parameters.

\section{A. The Model}

We analyse a dispute over a cartel damages payment $P$ between a claimant $C$ and a defendant $D$. Such a dispute will be initiated by the claimant and can result in either a settlement agreement or in a final judgment by the court. We assume that the claimant and the defendant have the same settlement costs $S$ and the same litigation costs $L .{ }^{43}$ Settlement costs are lower than litigation costs, i.e. $S<L$.

In case of a final judgement, a court will decide on the damages payment $P^{L}$. When settling, the companies agree upon a damages payment. The expected outcome of the court ruling $\hat{P}^{L}$ forms the

\footnotetext{
${ }^{40}$ In an ideal setting one would also want to calculate the true damages and benchmark the received payments to those. This approach would allow to rule out situations of over-compensation. However, the level of true damages is not easily calculated and regularly a focus of dispute.

${ }^{41}$ The only final judgement on private damages related to an EU cartel case for which all remedies have been exhausted is to our knowledge the vitamins judgment from 2001. While the percentage amount is rather significant (around 15\% of the affected commerce), the total amount awarded (around 1.5 Mio DM) is rather small given the record fines imposed by the Commission (EUR 855.22 million) and the rewarded damages in the US (\$ 2,297 million); see also Connor (2006), Appendix, Table 13, and Waelbroeck et al. (2004). In two other cases, Fluxx/ mybet Holding against the state lottery companies in Germany and Sainsbury against Mastercard in the UK, damages were awarded by courts, but the decisions were appealed thereafter.

42 Being limited to visible litigation is clearly a shortcoming. As long as the relevance of non-visible litigation does not change over time, this should not impact our assessment though.

${ }^{43}$ We do not analyse how different litigation cost allocation rules affect settlement amounts and the settlement timing. This is a simplification as litigation cost allocation rules differ across jurisdictions and litigation and settlement cost may differ for claimant and defendant, depending e.g. on the effort taken.
} 
basis for the settlement talks. Claimant and defendant can have diverging expectations of the damages payment that a court would set $\left(\hat{P}_{D}^{L} \leq \hat{P}_{C}^{L}\right)$.

Within this setting, the expected litigation payoff of the claimant is: ${ }^{44}$

$$
\pi_{C}^{L}=\frac{1}{(1+z)^{T}} \hat{P}_{C}^{L}-L
$$

Where the costs of litigation of the claimant have to be invested upfront, i.e. when the claim is brought, but can be recovered if an early settlement is achieved. ${ }^{45}$ Accordingly, the claimants' expected payoffs pursuant to a settlement is:

$$
\pi_{C}^{S}=P^{S}-S+L
$$

For the defendant the expected litigation payoff is as follows:

$$
\pi_{D}^{L}=-\frac{1}{(1+z)^{T}} \hat{P}_{D}^{L}-L
$$

For the defendant it is assumed that he has to invest the litigation costs only once no early settlement can be achieved. In case of a settlement the defendant's expected payoff pursuant to settlement is:

$$
\pi_{D}^{S}=-P^{S}-S
$$

Because litigation takes time $T$, the parties discount the expected damages payment a court would set with the interest rate $\%$. When settling, the parties agree on the Nash bargaining solution. In anticipation of the outcome of the court ruling and the decision to settle or not, the claimant takes the decision whether to litigate a case or not. Figure 3 illustrates the sequence of decisions and events assumed.

\footnotetext{
44 We assume risk neutrality here, an assumption which can be justified by the fact that claimants and defendants in competition litigation are typically corporations and not individuals. Still it has to be noted that risk aversion might be relevant also for corporations, which can impact the decision to settle (Perloff et al., 1996).

${ }^{45}$ Alternatively, one may assume that only a fraction of the litigation costs can be recovered, depending on the time elapsed within the proceedings.
} 
Figure 3: Illustration of sequence of decisions and events

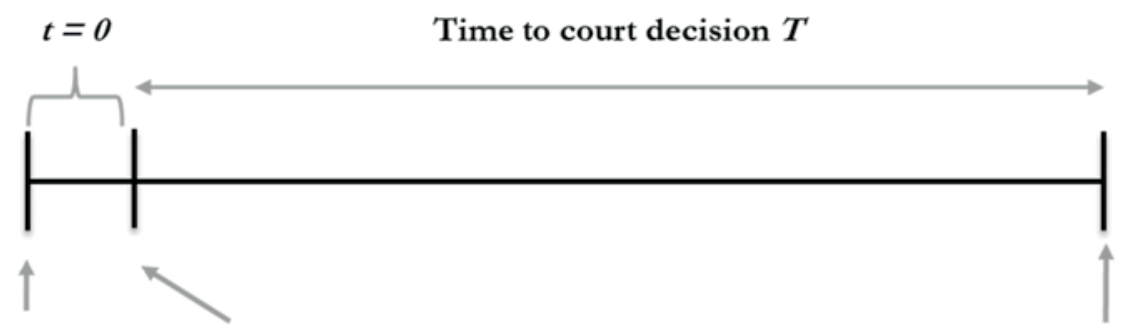

\begin{tabular}{|c||c|c|}
\hline $\begin{array}{c}\text { Decision to bring a claim; } \\
\text { taken by the claimant who } \\
\text { invests his litigation costs } \mathrm{L}\end{array}$ & $\begin{array}{c}\text { Decision for an early settlement; } \\
\text { agreed between claimant and } \\
\text { defendant; litigation costs } \mathrm{L} \text { invested } \\
\text { by defendant if settlement talks fail }\end{array}$ & $\begin{array}{c}\text { Court determines } \\
\text { compensation payment } \\
\text { through a final judgment }\end{array}$ \\
\hline
\end{tabular}

Source: The authors.

The framework allows to analyse two decision outcomes relevant for our policy question. First, it allows to analyse the conditions under which a claim is brought as a measure of litigation activity. Second, we can analyse the conditions under which an early settlement is achieved instead of full litigation in the court room, leading to a final judgement.

\section{Decision to bring a claim}

The decision to bring a claim is taken by the claimant. We assume that at point $\mathrm{t}=0$ the claimant has to (commit to) invest the full litigation costs L, required to win a final judgement. ${ }^{46}$ Under those assumptions the incentive constraint to litigate ("litigation condition") is the following. A claimant will litigate if its payoff from litigation $\left((1+z)^{-T} \hat{P}_{C}^{L}-L\right)$ is equal to or higher than zero:

$$
L \leq \frac{1}{(1+z)^{T}} \hat{P}_{C}^{L}
$$

This is the case if the discounted damages payment which the claimant expects under a court ruling is as high as or higher than litigation costs. It is noteworthy that the decision to bring a claim does not depend on the settlement solution. This is so because only in this case the claimant holds a credible outside option during settlement negotiations to finish the case successfully in the court and, hence, can achieve a valuable settlement agreement. ${ }^{47}$

\section{Solution to the settlement negotiations}

In the following we derive the payment in case a settlement is achieved. We assume Nash bargaining here. The Nash bargaining solution is determined by:

$$
\max _{P^{S}}\left(\pi_{D}^{S}-\pi_{D}^{L}\right)\left(\pi_{c}^{S}-\pi_{C}^{L}\right)
$$

As negotiated damages payment in the Nash bargaining solution, we receive:

\footnotetext{
${ }^{46}$ Under German civil law the claimant is actually required to have the funding to pay all litigation costs, even in the event of failure.

47 This would change if the litigation cost invested by the claimant would be sunk. In this case the litigation costs would work as a commitment device and allow litigation activity which only pays off in case of early settlement.
} 


$$
P^{S *}=\frac{1}{(1+z)^{T}} \frac{\hat{P}_{C}^{L}+\hat{P}_{D}^{L}}{2} .
$$

Thus, if the parties settle and under the extreme assumption of full litigation, i.e. court proceedings resulting in a final judgment, takes no time $(T=0)$, they will meet in the middle of their expectations about the damages payment a court would set. With litigation duration increasing the agreed upon damages payment decreases. The claimant will receive no payment if litigation takes very long $(T=\infty)$. Hover, in this parameter setting no claim will be brought in the first place as the discounted expected payment in case of full litigation is zero as well.

\section{Decision to settle}

A settlement is concluded if for both parties the settlement agreement is preferred over litigation. This is the case if for both parties the settlement payments plus the extra costs for litigation (i.e. the difference between litigation and settlement costs) are at least as high as the discounted payoffs they expect from a court ruling. Or put differently, the damages payment that the defendant is maximally willing to pay to the claimant for a settlement must be at least as high as the damages payment minimally demanded by the claimant from the defendant for a settlement to occur. This is the case if the following "settlement condition" holds:

$$
\frac{1}{(1+z)^{T}} \frac{\hat{P}_{C}^{L}-\hat{P}_{D}^{L}}{2} \leq L-S
$$

Thus, a settlement will be concluded if half the difference between the discounted damages payment the claimant expects a court to set and the discounted damages payment the defendant expects a court to set is lower than (or as high as) the difference between litigation and settlement cost.

At the beginning of litigation, claimants likely expect a higher damages payment assigned by court than defendants, as both claimants and defendants are typically optimistic regarding their own potential success in court. Therefore, the left hand side of the settlement condition is likely positive. As litigation costs exceed settlement costs, the right hand side of the settlement condition is positive as well. The left hand side of the settlement condition decreases with litigation duration $T$. If litigation in the court is expected to take long, the settlement condition is more likely to hold.

Based on the settlement condition, we conclude that the parameter range for a settlement to occur is larger in such situations where:

- the parties are not too optimistic regarding their own potential success in court and, hence, the divergence in expected payoffs is not too large, and/ or

- litigation costs significantly exceed settlement costs, and/or

- litigation duration is rather long.

It follows that expectations of the upcoming legal proceedings are of key importance. A settlement can only be reached if expectations of claimant and defendant regarding expected damages payments under a court ruling are "similar enough".

Furthermore, the avoidance of litigation cost may trigger a settlement before court proceedings start. If litigation costs are relatively low, they are less likely to "bridge" any gaps in expectations between the parties regarding the damages payment under a court ruling. 
Finally, a settlement becomes more likely if litigation duration is rather long. Claimant and defendant then discount the expected payments under a court ruling by more. Any difference in expectations consequently becomes less critical and can more easily be overcome. Note, however, that a long litigation duration also limits the incentives to bring a claim in the first place (see litigation condition).

\section{B. Impact of policy reforms on model parameters}

In the following, we explain within the theoretical framework the impact of policy reforms on (1) the number of private follow-on damages claims, (2) the number of settlements, and (3) the timing of settlements. Thereafter, we discuss implications for a constructive policy reform.

\section{Impact of policy reforms on litigation activity}

An objective of the current policy reform is to enable effective compensation of victims of competition harm. Given the historically limited scope, or rather non-existence, of litigation on cartel cases, this objective implies more private litigation activity. A policy reform can influence the number of private damages claims via several channels. As shown before the decision to bring a case is in the hand of the claimant and depends on his expectations regarding damages payments in case of a court ruling.

The parameter range within which litigation occurs is defined by the litigation condition, $L \leq$ $(1+z)^{-T} \hat{P}_{C}^{L}$. Three effects ${ }^{48}$ can be distinguished based on the impact of the reform on the litigation condition: ${ }^{49}$

(a) Increase of the expected damages payment in case of a court ruling, $\widehat{\boldsymbol{P}}_{\boldsymbol{C}}^{L}$, : A policy reform may have the goal to strengthen the position of claimants, increasing the claimant's expectation about the damages payment a court would set. If the claim becomes more valuable from the perspective of the claimant, i.e. if the claimant's expected damages payment under litigation, $\hat{P}_{C}^{L}$, increases, this will make litigation more likely.

(b) Reduction of the duration of court proceedings, T: A policy reform may reduce the required time for a final judgment, for instance, by streamlining the procedures or by resolving a lack of procedural clarity. This will unambiguously extent the parameter range for litigation activity as the net present value of the expected damages payment increases for the claimant.

(c) Reduction of the litigation costs, $L$ : A policy reform may also reduce the transaction costs of litigation. In this case, full-blown court proceedings become less costly compared, increasing the parameter range of litigation.

Obviously, a policy reform may affect several model parameters in parallel.

\footnotetext{
${ }^{48}$ In a richer model setting also the expectations of the dependant and settlement coat can play a role.

${ }^{49}$ Note that the settlement condition is also affected by policy reforms and hence the parameter range of settlements, which affect the decision to litigate as well. As these effects are second order, we do not discuss them further.
} 


\section{Impact of policy reforms on the number of settlements}

The parameter range within which settlements occur in equilibrium are defined by the settlement condition, $L-S \geq(1+z)^{-T}\left(\hat{P}_{C}^{L}-\hat{P}_{D}^{L}\right) / 2$. The following main parameters determine how policy reforms can affect the likelihood of settlements:

(a) Convergence of the parties' expectations regarding the outcome of court proceedings, $\widehat{\boldsymbol{P}}_{\boldsymbol{C}}^{L}-\widehat{\boldsymbol{P}}_{\boldsymbol{D}}^{L}$ : A policy reform may align expectations, and, hence, allow the parties to anticipate more consistently the outcome of court proceedings. This implies a lower difference between the damages payment the claimant expects a court would set and the damages payment the defendant expects a court would set $\left(\hat{P}_{C}^{L}-\hat{P}_{D}^{L}\right.$ decreases as both $\hat{P}_{C}^{L}$ and $\hat{P}_{D}^{L}$ converge to $\left.P^{L}\right)$. This makes a settlement more likely because it becomes easier for the parties to meet in the middle of their discounted expectations about the damages payment a court would set.

(b) Increase of the expected damages payment in case of a court ruling, $\widehat{\boldsymbol{P}}_{C}^{L}, \widehat{\boldsymbol{P}}_{D}^{L}$ : A policy reform with the goal to strengthen the position of claimants, most likely will increase both parties' expectation about the damages payment a court would set. While this will increase the parameter range of litigation activity (see earlier section) the parameter range for settlements will not change as long as both parties' expected damages payments increase by the same amount, i.e. as long as difference between the expected damages payments $\left(\hat{P}_{C}^{L}-\hat{P}_{D}^{L}\right)$ stays constant. In this case the level of conflict remains the same and the likelihood of settlements also remains the same. If a reform, however, results in more legal certainty and, hence, a lower level of conflict the parameter space for settlements increases in parallel with a higher litigation activity.

(c) Reduction of the duration of court proceedings, T: Counterintuitively, a policy reform, which reduces the required time for a final judgment, will negatively affect the parameter range of settlements because claimant and defendant discount the expected payments under a court ruling by less and, hence, are more willing to battle it out in the court room. Any difference in expectations then becomes more critical and can be overcome less easily. However, with the duration of court proceedings become shorter the litigation activity increases. ${ }^{50}$

(d) Reduction of the difference between litigation and settlement costs, $L-S$ : A policy reform, that reduces the transaction costs of litigation, makes full-blown court proceedings less costly compared to settlements (assuming that the costs for reaching a settlement are not reduced in parallel through the reform). Ceteris paribus, such a policy reform can be expected to result in less settlements (but, again, more litigation activity in general).

\footnotetext{
${ }^{50}$ In a more complex dynamic setting (see also later section on timing), earlier settlements may be observed if settlements often occur just before final judgments, e.g. to avoid public/ unfavourable judgments. Then a reduction of the duration until court time will imply that settlements are often concluded earlier. As we are focusing on the first settlement in our empirical assessment those are not relevant for our analysis and, therefore, not modelled.
} 


\section{Impact of policy reforms on the timing of settlements}

For simplification, we have developed our arguments within a static modelling framework. In this static framework either an early settlement is brought or a final judgement after a fixed time period $\mathrm{T}$ is delivered.

In the following, we argue that the conditions that result in an extended parameter range for settlements (see above) coincide with the conditions for early settlements in a more complex dynamic framework.

For that purpose, we assume that the parties update their expectations regarding the damages payments a court would award. In particular, in each time period $t, t \leq T$, the parties' expectations regarding the damages payment under litigation converge to a certain degree, i.e. in the settlement condition the term $\hat{P}_{C}^{L}-\hat{P}_{D}^{L}$ decreases over time. We assume that this positive effect of the update of the parties' expectations overweighs any possible negative effects due to (1) a shortening of the time until the end of litigation (i.e., when moving closer to the final court decision, the discount factor converges to one which ceteris paribus increases the level of conflict) or (2) a decrease in the difference between litigation and settlement costs (e.g., because of sunk litigation costs over time). Under these assumptions, the settlement condition becomes less of a constraint with $t$ moving closer to $T .^{51}$

We also assume that a settlement will be reached at the first point in time at which the settlement condition is satisfied. ${ }^{52}$ For example, a settlement may be reached after disclosure of important information, which may trigger a discontinuous jump in the expected damages payments under a court ruling. Finally, we assume that in case the settlement condition is at no point in time satisfied, the case will be decided by court.

In such a setting, the above derived conditions for a higher likelihood of a settlement in response of a policy reform translate into earlier settlements. The following figure illustrates this.

\footnotetext{
${ }^{51}$ For instance, if one assumes that shortly before the court decision the parties share the same expectations on the court outcome and litigation costs are still larger than settlement cost, e.g. due to extra court payments for judgment or reputational costs for one party in case of a public judgement, a settlement will always be preferred over a final judgment. 52 This may not be the case if claimants and defendants optimize their financial position over time, e.g. if a later settlement is more profitable for one side the party may not agree to an early settlement even if it is better than no settlement at all.
} 
Figure 4: Illustration of the relation between the parameters of the settlement condition and settlement timing

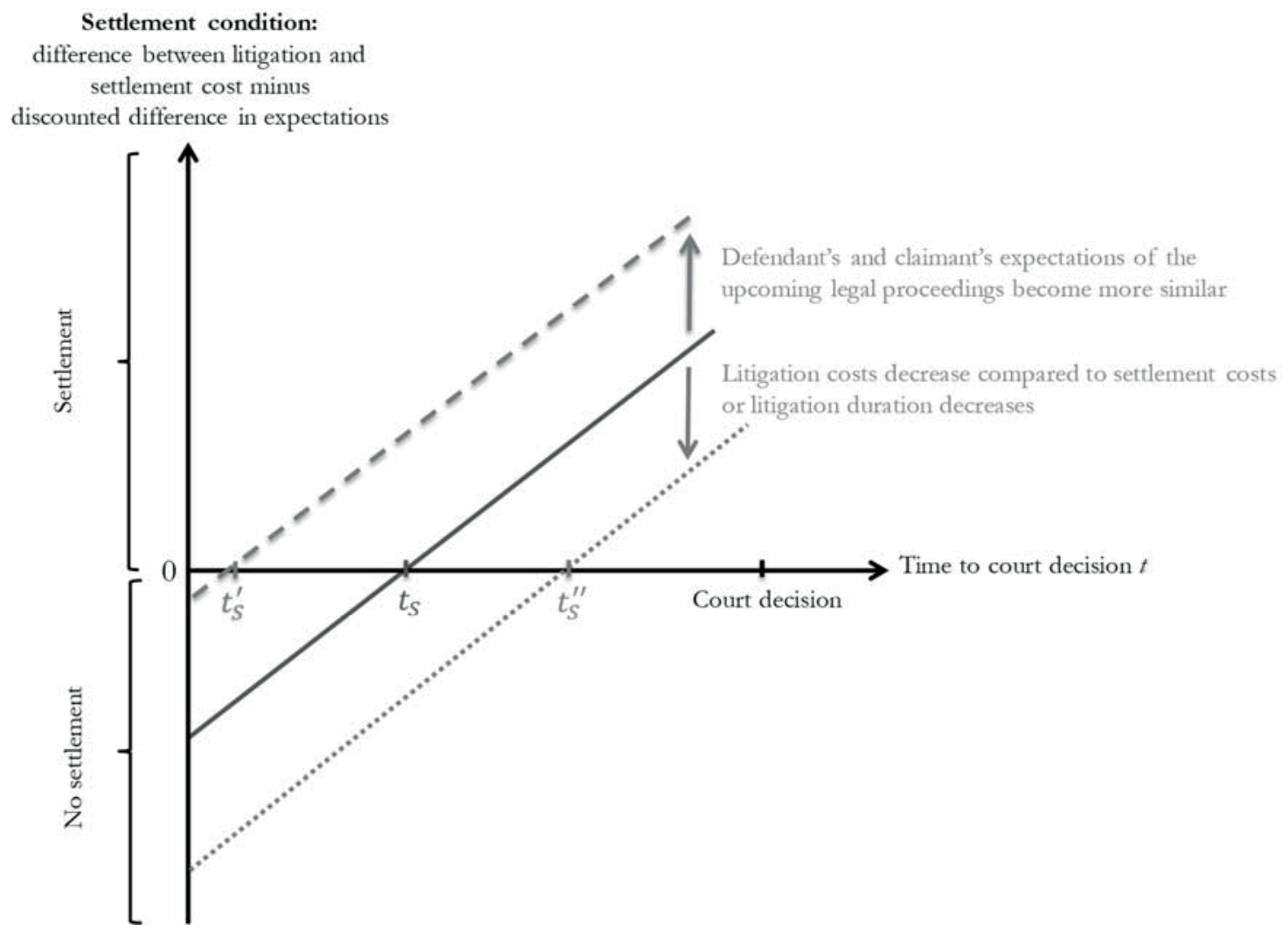

Source: The authors.

Expectations may diverge substantially at the beginning of the settlement talks at time $t=0$ (the solid line lies in the region of "no settlement" at the beginning). Over time, the parties may update their expectations due to additional evidence becoming available (the solid line increases over time). This should make settlements over time more likely (the solid line lies in the "settlement" region later on).

An increase in legal certainty due to a policy change will result in a reduction of the divergence of expectations between the parties. In the graph this is represented by an upward shift in the solid line (see upper dashed line in Figure 4), implying that at any point in time the parties' expectations diverge less and settlements will be reached earlier. While without such a policy change, settlements would occur at time $t_{S}$, with such a policy change settlements occur at time $t_{S}^{\prime}$.

The same logic applies to a policy change that decreases litigation costs compared to settlement costs or reduces the expected litigation duration $T$. In that case, the solid line shifts downwards (see lower dotted line in Figure 4), leading to later settlements at time $t_{S}^{\prime \prime}$. At any point in time, the parties' expectations then need to diverge less for a settlement to be reached. Hence, settlements will be reached later. Under the assumptions, see above, that reduction of the divergence of expectations between the parties dominates the other effects a policy that increases legal certainty results in early settlements. 


\section{Conclusions}

A policy reform, which has as objective to allow for effective compensation of victims in cartel infringement cases, ideally should exhibit some basic characteristics:

- an increase of the expected damages payment in case of a court ruling,

- an alignment of parties' expectations regarding the damages payment in case of a court ruling,

- a reduction of litigation costs,

- a reduction of litigation duration.

Based on our theoretical model, we expect such a reform to result in the following outcome regarding litigation activity and timing of settlements.

Table 2: $\quad$ Summary of the impact of a constructive policy reform on litigation activity and settlement timing

Elements of a constructive policy reform
Litigation activity

Likelihood of early settlements

\begin{tabular}{lcc}
\hline $\begin{array}{l}\text { Increase of the expected payment in case } \\
\text { of a court ruling }\end{array}$ & + & 0 \\
\hline $\begin{array}{l}\text { Alignment of parties' expectations } \\
\text { regarding a court ruling }\end{array}$ & 0 & + \\
\hline $\begin{array}{l}\text { Reduction of litigation costs } \\
\text { Reduction of litigation duration }\end{array}$ & + & $-/ 0$ \\
\hline
\end{tabular}

Source: The authors.

As can be seen, a policy reform that increases the expected damages payment in case of a court ruling and/ or reduces litigation costs and litigation duration, should have an unambiguous positive effect on litigation activity. A policy reform that leads to more legal clarity, aligning the parties' expectations regarding a court ruling, increases - under the plausible assumption that its impact on litigation costs and duration is less pronounced - the likelihood of (early) settlements. ${ }^{33}$ Accordingly, a reform process that increases the expected damages payment in case of a court ruling and leads to an alignment of parties' expectations, should result in higher litigation activity and the likelihood of early settlements will increase.

\footnotetext{
${ }^{53}$ Likewise indeterminate policy reforms may result in earlier settlements as claimants may start agreeing to settlements "in desperation" in order to avoid high litigation costs and long litigation. Importantly, in such a situation litigation activity will be low, given the low expected payments in case of a court ruling.
} 


\section{Empirical analysis}

Based on our theoretical model, we predict increasing litigation activity as a result of a constructive policy reform; early settlements will be the consequence in particular if the reform results in an alignment of parties' expectations regarding court ruling, i.e. increases legal certainty.

In this section, we present our empirical results on litigation activity and on the development of the timespan between public and private enforcement based on a dataset related to all Commission Decisions related to European cartel cases dated between 2001 and 2015.

\section{A. Dataset}

Our assessment focuses on follow-on damages claims related to EU cartel cases. ${ }^{54}$ To set up the dataset, we first researched all Commission Decisions related to European cartel cases dated between 2001 and 2015 based on the Commissions case repository. ${ }^{55}$

Second, we investigated whether after such a Commission Decision private damages were i) claimed and, subsequently, ii) a settlement reached. We gathered information on private enforcement activity, using the commercial databases MLex and PaRR.$^{56} \mathrm{We}$ also conducted a general search on the web and carried out telephone interviews with practitioners. ${ }^{57}$ Our research only reflects "visible litigation" activity; settlements which have been part of normal business negotiations and/ or have not left any public footprints are not included.

The dataset includes information on 90 cartel decisions by the Commission. For 38 of these cartel decisions, we found that private damages were claimed thereafter. Our search revealed that 92 settlements could be reached in 21 cases of private litigation. ${ }^{58}$

\section{B. Number of Commission Decisions and follow-on claims}

The following figure provides an overview of the number of Commission Decisions related to European cartel cases in each year since 2001. ${ }^{59}$ A distinction is made between larger and smaller cases. Larger cases are defined as cases, for which the total fines imposed with the Commission Decision exceed the median total fines in the periods until 2005 and from 2006 onwards.

\footnotetext{
${ }^{54}$ National cartel cases are hence not represented. Examples for national cartel cases are manifold and do trigger private litigation activity as well, e.g. the Germany cement cartel cases (see, e.g., Hüschelrath et al., 2013).

55 The Commission lists all cartel decisions at http://ec.europa.eu/competition/cartels/cases/cases.html.

56 The MLex website can be accessed via http://mlexmarketinsight.com/. The PaRR website can be accessed via https://www.parr-global.com/.

${ }^{57}$ We spoke to the following experienced litigation practitioners: Andreas Hahn, Partner Oppenländer; Paul Anthony Hitchings, Partner Cuatrecasas; Tillmann Makatsch, Head of Competition Litigation \& Antitrust Economics DB AG; Jolling de Pree, Partner De Brauw.

${ }^{58}$ Note that each defendant can conclude settlements with different claimants. In our statistics, two settlements would be counted if a defendant settled with two different claimants.

59 Those numbers can be compared to and are largely consistent with the numbers presented by Hellwig and Hüschelrath (2016, p. 7).
} 
Figure 5: Number of Commission Decisions related to European cartel cases, total and larger cases for 2001 to 2015

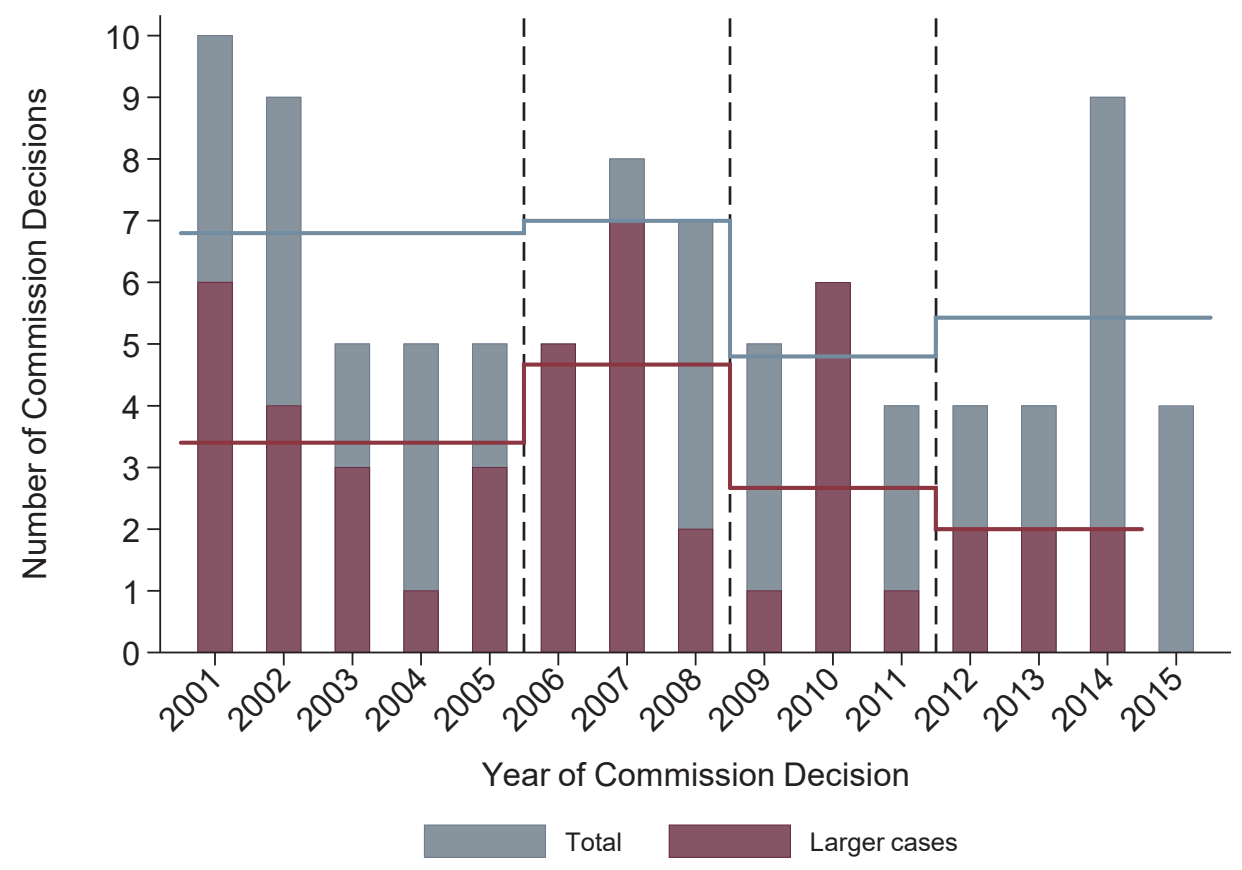

Note: This graph is based on 90 Commission Decisions. The horizontal black lines represent the simple averages of the yearly number of Commission Decisions for 2001-2005, 2006-2008, 2009-2011, and 2012-2015 respectively.

Source: The authors.

As can be seen, the number of Commission Decisions has been rather stable over time except for a few temporary peaks, which are accompanied by lows in the years before or thereafter. However, a minor tendency of a decreasing number of cases at EU level, especially of larger cases, is visible. By contrast, the number of smaller cases rose since 2008. Overall, we observe on average six decisions per year over the years 2001 to 2015, with 90 Commission Decisions in total. The average number of six Commissions Decisions per year stays in stark contrast to the average of one cartel case per year as observed during the period 1958 to $1998 .^{60}$

In the following, we present evidence on the current private litigation activity throughout Europe. We focus on follow-on claims, i.e. claims following public enforcement, related to European cartel cases with a Commission Decision dated between 2001 and 2015.

Figure 7 depicts for each year of a Commission Decision, the share of cases for which private damages litigation has been initiated in later years.

${ }^{60}$ C. Harding and J. Joshua, Regulating Cartels in Europe: A Study of Legal Control and Corporate Delinquency, Oxford: Oxford University Press, 2003, Chapter V and Table V.1: "Cartels dealt with by the Commission 1964-1987". Cited according to Riley (2010). The total number of cases brought by the Commission under Art. 101, 102 or 106 FEU Treaty is significantly higher and lies at around 10 cases per year over the period 1968 to 2008 according to Russo et al. (2010). 
Figure 6: $\quad$ Share of cases litigated, 2001 to 2015

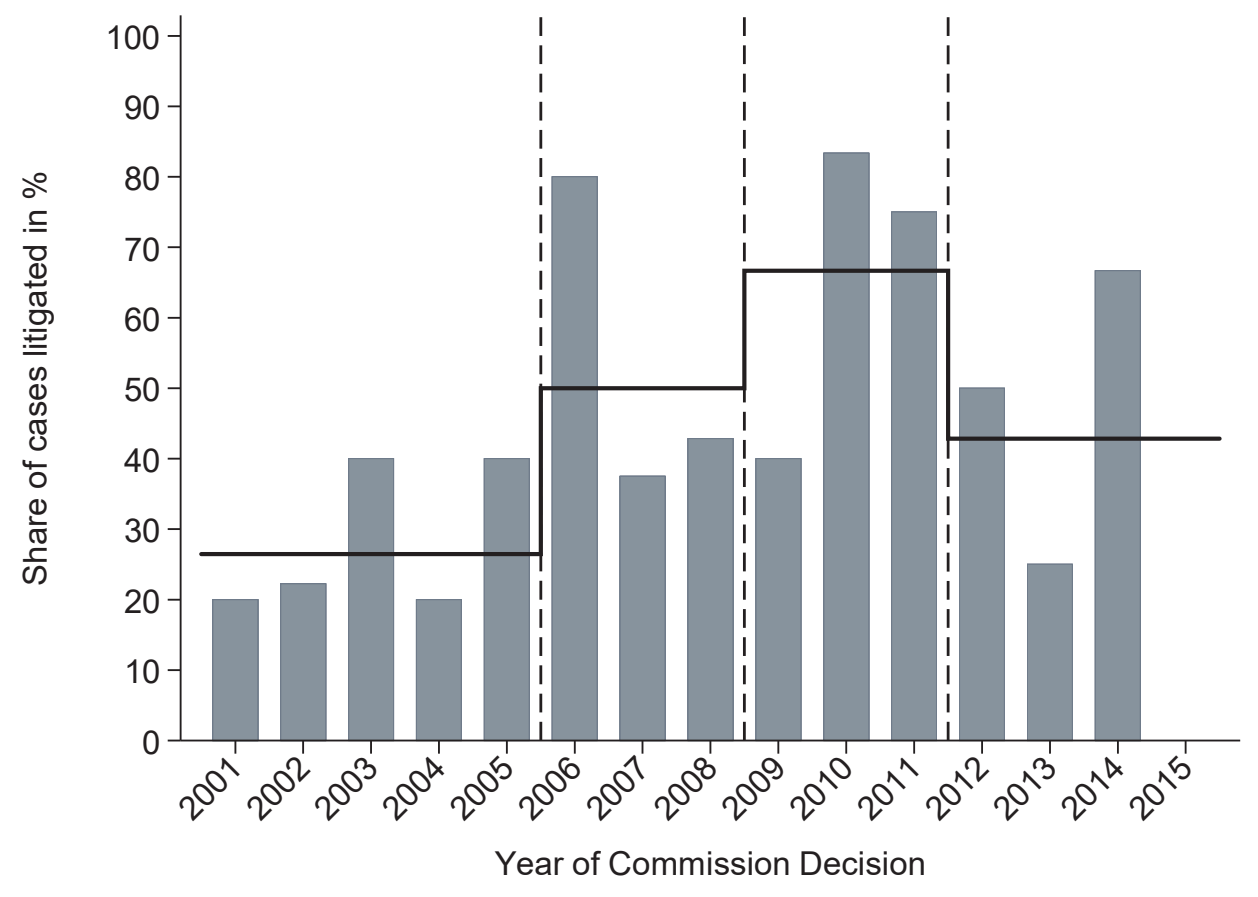

Note: The figure is based on 38 observations on private damages litigation between 2001 and 2015, following 90 cartel decisions by the Commission. Note that there might be multiple parallel proceedings for a single case in various jurisdictions, which are counted as one. We recorded no private damages litigation for cases decided in 2015. The horizontal black lines represent the averages of the share of cases litigated, weighted by the number of Commission Decisions in that year.

Source: The authors.

It becomes visible that private damages litigation was "taking off' in 2001 and increased over time until 2011. Since then the share of total cases litigated decreased again but remained on a relatively high level.

The latest decrease in the share of total cases litigated can in part be explained by a higher share of smaller cases decided since then by the Commission. As shown in Figure 7, smaller cases saw no private litigation until 2008. Since then, not only the number of smaller cases but also the share of smaller cases being litigated increased substantially. As the share of smaller cases litigated still remained below the share of larger cases litigated, the higher share of smaller cases led to a decline in the share of total cases litigated. 
Figure 7: $\quad$ Share of cases litigated, larger and smaller cases, 2001 to 2015

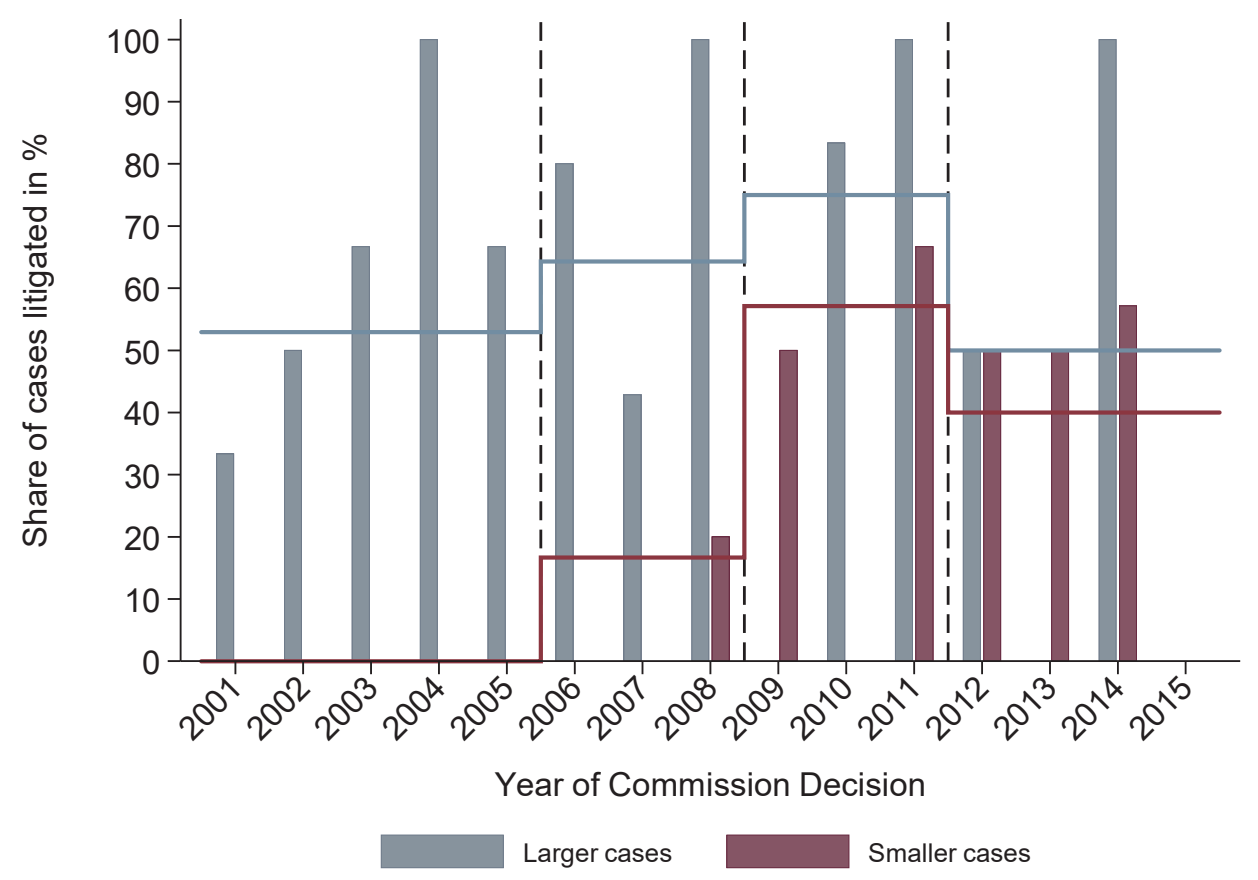

Note: The figure is based on 38 observations on private damages litigation between 2001 and 2015, following 90 cartel decisions by the Commission. Note that there might be multiple parallel proceedings for a single case in various jurisdictions, which are counted as one. We recorded no private damages litigation for cases decided in 2015. The horizontal black lines represent the averages of the share of larger/ smaller cases litigated, weighted by the number of Commission Decisions on larger/ smaller cases in that year. Larger cases are defined as cases, for which the total fines imposed with the Commission Decision exceed the median total fines in the periods until 2005 and from 2006 onwards.

Source: The authors.

\section{Timespan between public and private enforcement}

In the following, we present evidence on the number of years between Commission Decisions related to European cartel cases between 2001 and 2015, the first follow-on private damages litigations, and the first publicly announced settlements.

Figure 8 shows important events during the administrative and private enforcement of cartel cases. 
Figure 8: Timeline of a typical litigation case

Duration between EC decision and settlement
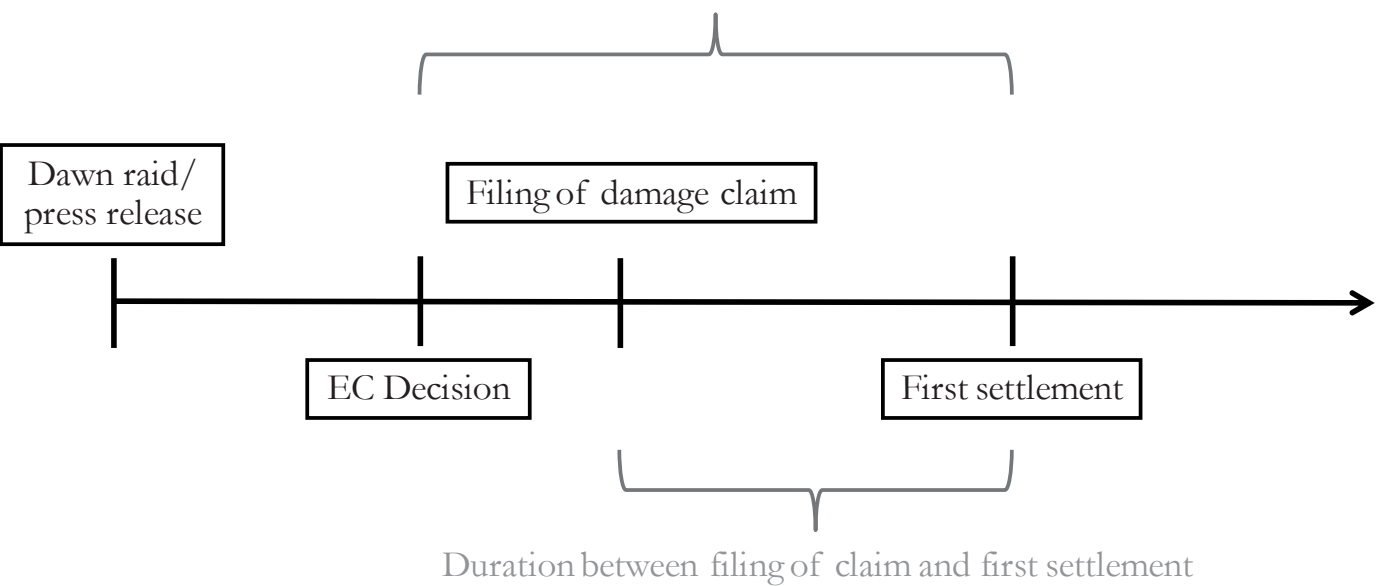

Source: The authors.

Our main measure for the duration of settlement negotiations is the timespan between the adoption of a Commission Decision and the first publicly announced settlement. ${ }^{61}$ A few points are worth noting.

First, the limitation period limits the maximum time available until a follow-on private damages claim is brought. The limitation period typically starts at the point in time the infringement ceased, and the claimant could become aware of the infringement and had sufficient information to bring its claim. The specific provisions can vary from country to country and are affected by the reform process: the Directive on Antitrust Damages specifies in Article 10 that the limitation period for bringing actions for damages shall be at least five years and not begin to run before the infringement ceased and the claimant knows, or can reasonably be expected to know about the infringement. As a consequence, at least five years after the publication of a Commission Decision, cases can still be brought and, hence, might only then become visible. This duration might increase substantially in case the Commission Decision is appealed by (at least some) defendants or due to some mutual agreements between the parties which may extent minimum limitation periods. ${ }^{62}$ Accordingly, the litigation activity that is visible today represents only a part of the overall picture. Specifically, for the most recent cases a potential truncation problem exists.

Second, the timespan until the first settlement after the adoption of the Commission Decision can also be negative if claimants built their case on information available from press releases or their internal knowledge of the infringement. In such a setting, a claim can be brought and a first settlement might occur rather quickly after the down raid.

${ }^{61}$ The average duration of an administrative investigation, i.e. from the dawn raid to the adoption of the decision lies typically between 40 to 60 month and was rather stable over the period 2001 to 2015, with some delay in 2010 and a decrease of the average duration in the more recent years 2010 to 2015. See Hüschelrath and Marvao (2016, Figure 17, p. 26).

62 Actually, the appeal rate was rather high until 2010. Around $60 \%$ of all firms being fined by the Commission for cartel infringements appealed to European courts. This number declined to $21 \%$ in the years 2011 to 2015. According to Hüschelrath and Marvao (2016, p. 42/43), the reason for this decline most likely is the introduction of the settlement procedure in the administrative proceedings as one of the requirements of a settlement with the Commission is the admittance of liability. 
Third, we only observe (first) settlements for cases where a claim is brought at some national court.

We make the following observations with respect to the timing of private follow-on claims. As can be seen in Figure 9, for early cartel cases decided between 2001 and 2005 it could take up to nearly five years until the first damages claim was filed. Thereafter, the duration until the first damages claim seems to have drastically decreased. Between 2006 and 2015, the average duration until the first damages claim varied between 1.5 and 2.6 years.

Figure 9: Time between Commission Decision and first private claim

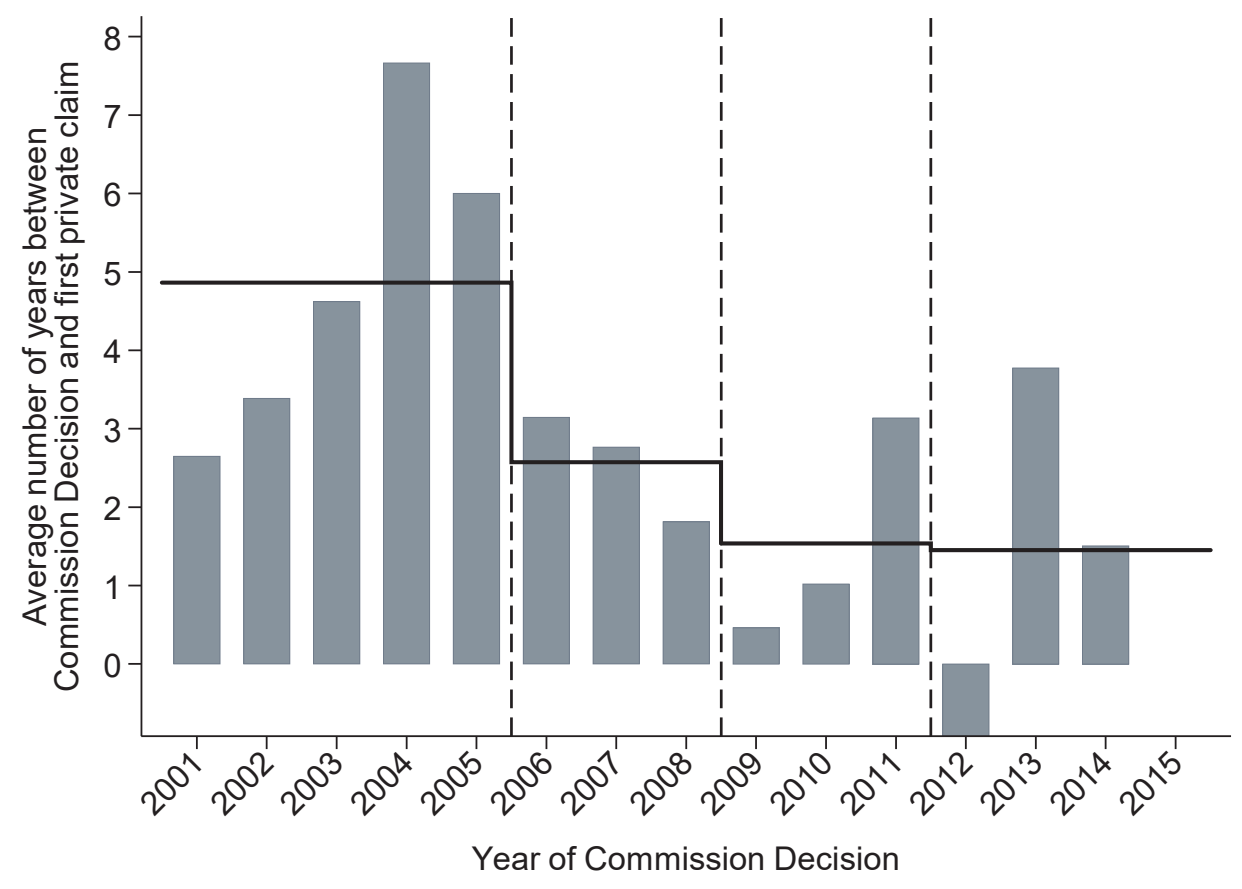

Note: The figure is based on 35 observations. For three litigated cases, there is no information on the date of the claim. The horizontal black lines represent the average of the number of years until the first follow-on private litigation case was brought for the periods 2001-2005, 2006-2007, 2009-2011, and 2012-2015 respectively, where each yearly observation is weighted with the number of Commission Decisions in that year.

Source: The authors.

Figure 10 presents evidence on the minimum number of years between the initiation of private damages litigation (following Commission Decisions related to European cartel cases between 2001 and 2015) and first settlements. Since there are often several private claims in each case, the claim, for which the shortest time span until the first settlement is observable, must not coincide with the first claim brought. 
Figure 10: Minimum time between private claim and first settlement, 2001 to 2015

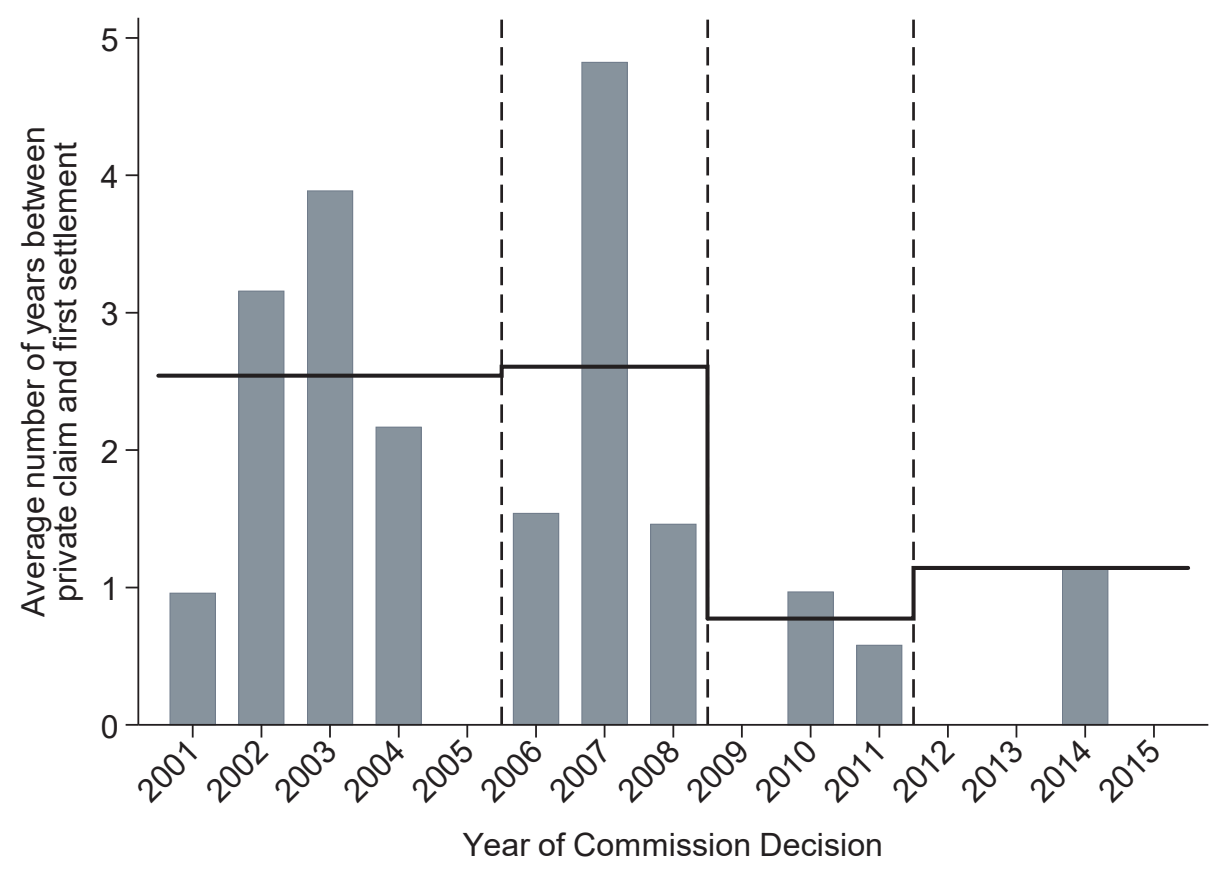

Note: The figure is based on 21 observations. As various claims can be brought for one decision we calculated the minimum time between a claim and a related first settlement for each decision. The horizontal black lines represent the average of the number of years for the periods 2001-2005, 2006-2007, 2009-2011, and 2012-2015 respectively, where each yearly observation is weighted with the number of Commission Decisions in that year.

Source: The authors.

As indicated in Figure 10, the duration between the initiation of private litigation and first settlements has decreased in recent years.

The following figure presents evidence on the number of years between the Commission Decisions related to European cartel cases between 2001 and 2015 and first settlements. 
Figure 11: Time between Commission Decision and first settlement, 2001 to 2015

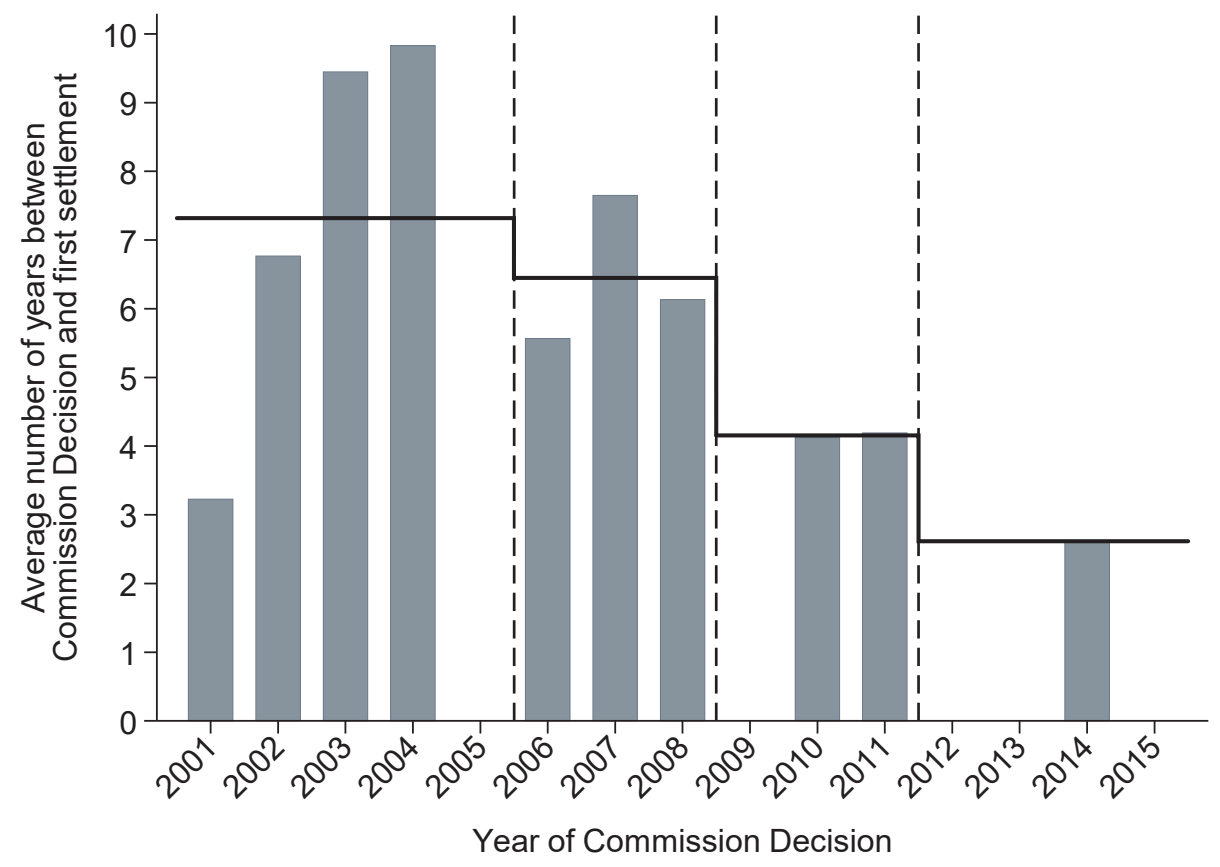

Note: The figure is based on 21 observations. The horizontal black lines represent the average of the number of years for the periods 2001-2005, 2006-2007, 2009-2011, and 2012-2015 respectively, where each yearly observation is weighted with the number of Commission Decisions in that year.

Source: The authors.

Figure 11 provides evidence that the duration between Commission Decisions and first settlements has decreased in recent years. While in 2001 to 2004 it took on average 7.3 years until a first settlement was reached after the Commission had decided a case, in 2006 to 2008 the duration fell to 6.4 years, in 2010 to 2011 to 4.2 years and in 2014 to 2.6 years. In the appendix we tests we can exclude that this trend towards shorter durations is driven by truncation. ${ }^{63}$

\footnotetext{
${ }^{63}$ First, it has to be noted that under the observed average duration of three years for the last cohort (2012 to 2015) no truncation problem occurs as we investigated all settlements until spring 2019, i.e. allowing for an observation period of more than 3 years. Second, in order to further check for a truncation bias we dropped, also for earlier cohorts, all observations for which the duration was larger than $\mathrm{x}$ years and restricted the sample to the time period until 2019 minus $\mathrm{x}$, where $\mathrm{x}$ is the number of years (namely 11 and 10 years for the first two cohorts and 7 and 8 for the second and third cohort; for the last cohort we cannot apply the test due to data limitations). Within this restrained dataset even for the latest decision date no "extra" truncation occurs. Hence, any reduction in average duration is not due to a truncation bias; still we observe a downward trend in the duration. Please note that this a conservative test as longer durations typically occur in earlier cohorts and are (falsely) disregarded by this test. See the Appendix for details.
} 


\section{Conclusions}

Based on a theoretical model and in light of the empirical findings we conclude that the European Commission's policy reform was a success up to now. This is based on the following reasoning:

First, in order to induce substantially higher private litigation activity a policy reform has to increase the claimant's expectations about the amount of damages being awarded, and/or must have induced lower litigation costs or shorten the expected duration until a final court judgement is delivered. Given that we observe a higher litigation activity the policy reform must have had a positive impact on those factors.

Second, the increase of litigation speed, measured by the number of visible early settlements, implies an alignment in the expectations of claimants and defendants in the final amount of damages being awarded. This is consistent with the European Commission reaching its objective to clarify and harmonize legal concepts across Europe.

Clearly, also other factors may have caused this development towards higher litigation activity and speed. For example, the experience gained over time by both defendants and claimants and their external consultants may have reduced litigation costs and allow speedier negotiation processes. However, this development seems to be deeply intertwined with the political reform process and, hence, cannot be considered an independent (albeit important) factor.

Further, higher litigation costs caused through the promotion of litigation in multiple jurisdictions can make settlements more likely and hence may lead to earlier settlements. It seems unlikely, though, that higher litigation costs due to litigation in multiple jurisdictions has been the key driver of the development as most of the visible litigation action during the observation period was centred on a few countries, namely UK, Germany and the Netherlands. More in general the lasting high level of litigation activity speaks against higher litigation costs. To the opposite: the higher share of smaller cartel cases being litigated indicates a reduction in litigation costs.

Another potential limitation is the issue of truncation in the data. Assuming for example that it takes ten years from the decision date until a first settlement is reached, then we will see the full picture for cartel decisions in 2015 only until 2025. Hence, the reduction of the timespan until first settlements may simply be driven by data truncation. To rule this out we conduct truncation tests, in which we restrict the observation period to the period e.g. until 2012 and exclude all observations with a first settlement after five years or more, hence applying the same truncation for all decision dates. Also in these truncation tests a shortening of the time until first settlement is observable. 


\section{Bibliography}

Aguzzoni, G., Langus, G., and Motta, M. (2013), "The effect of EU antitrust investigations and fines on the firm valuation", Journal of Industrial Economics, 61(2), 290-338.

Bourjade, S., Rey, P. and Seabright, P. (2009), "Private Antitrust Enforcement in the Presence of PreTrail Bargaining", Journal of Industrial Economics, 57(3), 372-409.

Boyd, C. L. and Hoffman, D. A. (2013), "Litigation Toward Settlement", The Journal of Law, Economics, and Organization, 29(4), 898-929.

Carree, M., Günster, A. and Schinkel, M.-P. (2010), "European Antitrust Policy 1957-2004: An Analysis of Commission Decisions", Review of Industrial Organization, 36, 97-131.

Connor, J. M. (2006), “The Great Global Vitamins Conspiracies”, SSRN Working Paper.

Fenn, P. and Rickman, N. (1999), "Delay and Settlement in Litigation", The Economic Journal, 109(457), 476-491.

Friederiszick, H. W. (2013), "The Damages Lie in the Details: Why the Proposed Directive Fails in Harmonizing Incentives to Sue Across the European Union“, CPI Antitrust Chronicle.

Geradin, D. and Sadrak, K. (2017), "The EU Competition Law Fining System: A Quantitative review of the Commission Decision between 2000 and 2017“, TILEC Discussion Paper 2017-018.

Ghosal, V. and Sokol, D. D. (2016), "Policy Innovations, Political Preferences, and Cartel Prosecutions", Review of Industrial Organization, 48: 405.

Harding, C. and Joshua, J. (2003), "Regulating Cartels in Europe: A Study of Legal Control and Corporate Delinquency", Oxford: Oxford University Press, Chapter V.

Hellwig, M. and Hüschelrath, K. (2016), "Cartel cases and the cartel enforcement process in the European Union 2001-2015: A quantitative assessment”, ZEW Discussion Paper 16-063.

Hellwig, M., Hüschelrath, K. and Laitenberger, U. (2018), "Settlements and Appeals in the European Commission's Cartel Cases: An Empirical Assessment”, Review of Industrial Organization, 52, 55-84.

Hüschelrath, K., Müller, K. und Veith, T. (2013), "Concrete Shoes for Competition: The Effect of the German Cement Cartel on Market Price", Journal of Competition Law and Economics, 9 (1), 97-123.

Johnston, J. S. and Waldfogel, J. (2002), "Does Repeat Play Elicit Cooperation? Evidence from Federal Civil Litigation", Journal of Legal Studies, 31(1).

Laborde, J.-F. (2017), "Cartel damages claims in Europe: How courts have assessed overcharges", Concurrences $\mathrm{N}^{\circ}$ 4-2017.

Lande, R and Davis, J. (2008), "Benefits from Private Antitrust Enforcement: An Analysis of Forty Cases", University of San Francisco Law Review, 42, 879-918.

Perloff, J. M., Rubinfeld, D. L. and Ruud, P. (1996), “Antitrust Settlements and Trial Outcomes”, Review of Economics and Statistics, 78, 401-409. 
Peyer, S. (2012), "Private antitrust litigation in Germany from 2005 to 2007: Empirical evidence", Journal of Competition Law and Economics, 8(2), 331-359.

Renda, A., Peysner, J., Riley, A. J., Rodger, B. J., Van den Bergh, R., Keske, S., Pardolesi, R., Camilli, E. L., and Caprile, P. (2008), "Making antitrust damages actions more effective in the EU: welfare impact and potential scenarios", Report for the European Commission.

Rengier, L. (2018), "Kartellschadensersatz in Deutschland - die ersten 15 Jahre in Zahlen und Lehren für die Zukunft", Wirtschaft und Wettbewerb 1284862.

Riley, A. (2010), “The Modernisation of EU Anti-Cartel Enforcement: Will the Commission Grasp the Opportunity?”, CEPS Special Report.

Rodger, B. J. (2008), "Private enforcement of competition law, the hidden story: competition litigation settlements in the United Kingdom, 2000-2005”, European Competition Law Review, 29(2), 96-116.

Rodger, B. J. (2009), "Competition law litigation in the UK courts: a study of all cases 2005-2008-Part I" Global Competition Litigation Review, 93-114.

Rodger, B. (2013a), "Competition law litigation in the UK courts: a study of all cases 2009-2012", Global Competition Litigation Review, 6(2), 55-67.

Rodger, B. J. (2013b), "Why not court? A study of follow-on actions in the UK", Journal of Antitrust Enforcement, 1(1), 104-131.

Rodger, B. J. (2015), "Private enforcement of competition law, the hidden story part II: competition litigation settlements in the UK, 2008-2012", Global Competition Litigation Review, 8(3), 89-108.

Rubinfeld, D. L. (2015), “Antitrust Settlements”, In: Blair, R.D. and Sokol, D. D., The Oxford Handbook of International Antitrust Economics, Vol. I, Chapter 7, p. 172 - 186.

Russo, F., Schinkel, M. P., and Günster, A. (2010), "European commission decisions on competition economic perspectives on landmark antitrust and merger cases", Cambridge: Cambridge University Press.

Sailer, K. (2019), "Update on development of follow-on damages claims: 2000-2018", available at http://www.econ-da.com/post.

Schinkel, M. P. (2007), "Effective cartel enforcement in Europe”, World Competition, 30(4), 539-572.

Smuda, F., Bougette, P. and Hüschelrath, K. (2014), "Determinants of the duration of European appellate court proceedings in cartel cases", ZEW discussion paper 14-062.

Spagnolo, G. and Marvao, C. (2016), "Cartels and Leniency: Taking Stock of What We Learnt", Stockholm Institute of Transition Economics, Working Paper No 39.

Spier, K. E. (1992), “The Dynamics of Pretrial negotiation”, Review of Economic Studies, 59(1), 93-108.

Spier, K. E. (2007), "Litigation”, In: Polinsky, A. M. and Shavell, S., Handbook of Law and Economics, Vol. 2, Elsevier, Chapter 4. 
Stephan, A. (2009), “An empirical assessment of the European Leniency notice”, Journal of Competition Law and Economics, 5, 537-561.

Walbroek, D., Slater, D. and Even-Shoshan, G. (2004), "Study on the conditions of claims for damages in the case of infringement of EC rules - Comparative Report", Ashurst. 


\section{Appendix 1 - Truncation Test}

We test whether the reduction in average duration time is caused by truncation of the sample, i.e. for later decisions the observation period is shorter than for earlier decisions inducing thereby potentially a shorter duration.

To test whether the reduction in average duration from the first cohort (2001 to 2005) to the second cohort (2006 to 2008) is affected by such a truncation bias we exclude all observations with a duration of more than 10 or 11 years respectively. As we observe settlements until beginning of 2019, within this restrained dataset even for the latest decision date (2008) no "extra" truncation occurs. Hence, any reduction in average duration is not due to a truncation bias. Please note that this a conservative test as longer durations typically occur in earlier cohorts and are (falsely) disregarded by this test.

Figure 12: Truncation Test Period 2001-2005 vs. 2006-2008, observations below or equal 11 and 10 years only
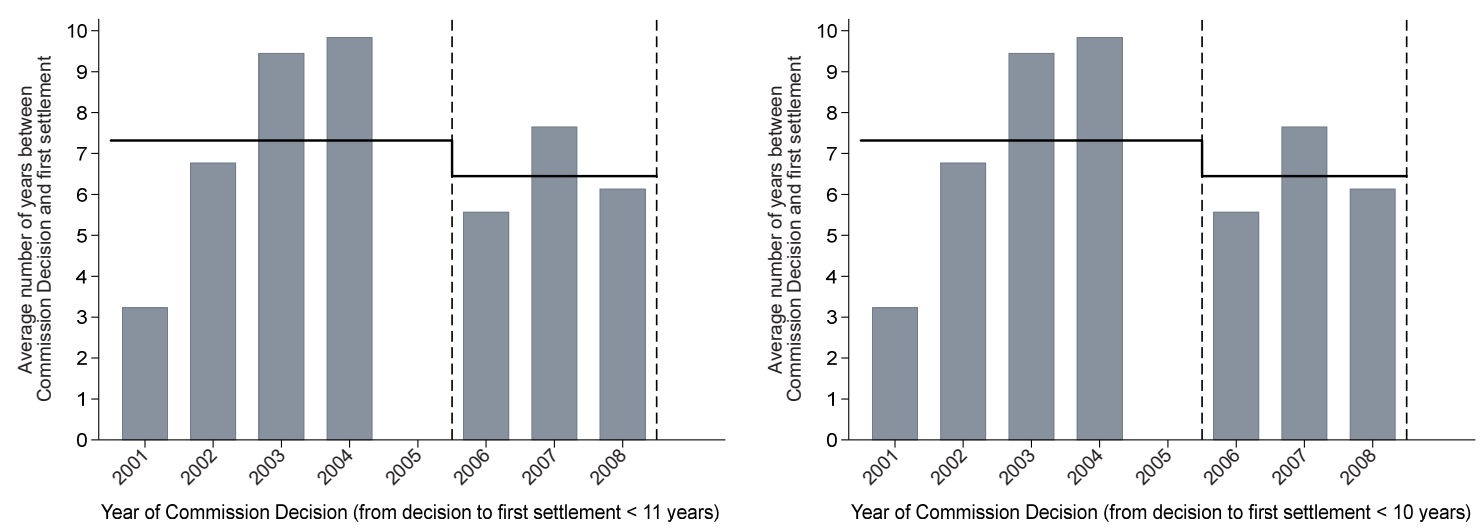

Source: The authors.

As can be seen in Figure 12 dropping all observations with a first settlement later than 11 and 10 years respectively leads to a reduction by 0.87 years as shown in Figure 12 . This is identical to the average duration without dropping any data. As can be seen in Figure 11 there the average duration until first settlement also drops by 0.87 years, namely from 7.32 years for the first cohort (2001-2005) to 6.45 years on average for the second cohort (2006-2008).

Equally, we test for the truncation bias for the decline in average duration between the second (20062008) and the third cohort (2009-2011). 
Figure 13: Truncation Test Period 2006-2008 vs. 2009-2011, observations below or equal 8 and 7 years only
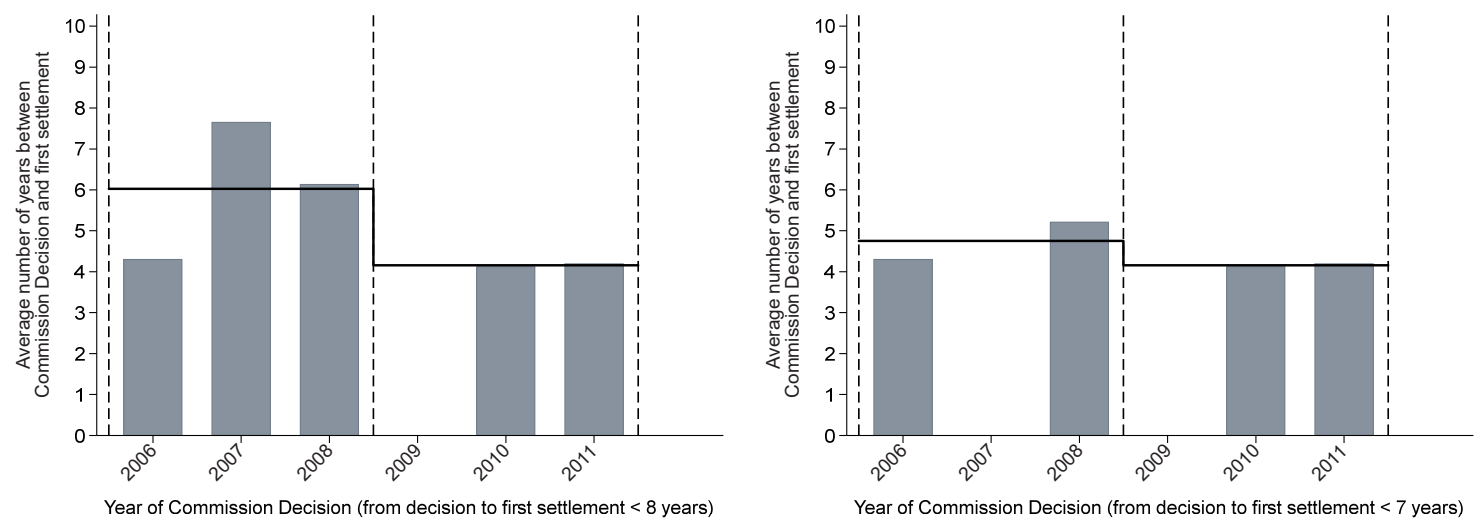

Source: The authors.

When dropping all observations with a duration to a first settlement duration larger than 8 and 7 years, respectively, we still observe a reduction by 1.87 years and 0.6 years as shown in Figure 13. For comparison (see Figure 11), the average duration until settlement in the unconstrained dataset drops by 2.29 years comparing the second cohort (2006-2008; average: 6.45 years) to the third cohort (20092011; average: 4.16 years). Hence, we cannot exclude some truncation bias to be at work. However, the qualitative results appear robust. Again, it has to be noted that the test is conservative and the test does not allow to conclude that a truncation bias, even if limited, is relevant. For the final cohort (20122015) a truncation test is not feasible given the limited observations and the reduced observation window. 


\section{Recent ESMT Working Papers}

ESMT No.

Beyond retail stores: Managing product proliferation along the supply chain

$19-02$

Işık Biçer, Rotterdam School of Management, Erasmus Universtiy

Florian Lücker, Cass Business School, University of London

Tamer Boyaci, ESMT Berlin

Marginality, dividends, and the value in games with externalities

19-01

Frank Huettner, ESMT Berlin

André Casajus, HHL Leipzig Graduate School of Management

Consumer choice under limited attention when alternatives have different

16-04 (R3) information costs

Frank Huettner, ESMT Berlin

Tamer Boyacı, ESMT Berlin

Yalçın Akçay, Melbourne Business School

Opaque queues: Service systems with rationally inattentive customers

18-04

Caner Canyakmaz, ESMT Berlin

Tamer Boyaci, ESMT Berlin

The Coleman-Shapley-index: Being decisive within the coalition of the interested

18-03

André Casajus, HHL Leipzig Graduate School of Management

Frank Huettner, ESMT Berlin 